\title{
14. GEOCHEMISTRY OF DEEP SEA SEDIMENTS FROM THE NANKAI TROUGH, THE JAPAN TRENCH, AND ADJACENT REGIONS1
}

\author{
Yoshitaka Minai, Department of Chemistry, Faculty of Science, University of Tokyo \\ Ryo Matsumoto, Geological Institute, Faculty of Science, University of Tokyo \\ and \\ Takeshi Tominaga, Department of Chemistry, Faculty of Science, University of Tokyo ${ }^{2}$
}

\begin{abstract}
Sediments from Sites 582 (11 samples), 583 (19 samples), 584 ( 31 samples), 294 (1 sample), 296 (9 samples), 297 (3 samples), 436 (11 samples), and 439 (3 samples) were analyzed by X-ray fluorescence and/or instrumental neutron activation analysis. Ten major elements and 24 minor and trace elements (including 7 rare earth elements) were determined with these methods. Geochemistry varies systematically with both the site location and sediment age. Such variations are explained in terms of changes in sedimentation processes caused by plate motion and changes in ocean currents.
\end{abstract}

\section{INTRODUCTION}

Geochemical data on deep-sea sediments have accumulated rapidly in the last 15 years, but at a slower pace than data on lithology, geology, and geophysics. In particular, the information concerning abundances of trace elements such as the rare earth elements (REE) is too scarce to permit resolution of several problems in earth sciences. For the sediments collected by DSDP, even the major element geochemistry has not been examined for all sites, and minor or trace element geochemistry has been reported for only a few. Although the REEs are useful for drawing inferences regarding the origin of constituent materials and for understanding processes and environments of sedimentation, their abundances in the DSDP sediment samples are reported in only a few papers (e.g., Dymond et al., 1976; Bogdanov et al., 1976; Tarney and Donnellan, 1977).

In this chapter, we report concentrations of major, minor, and trace elements, including REEs, in sediment samples collected at Sites 582 and 583 (Nankai Trough) and Site 584 (Japan Trench) during Leg 87 (Table 1; Fig. 1). For comparison, we have also analyzed deep-sea sediments from some nearby sites of other legs.

The objects of this study are the following:

1. Elucidation of the history of sedimentation processes by means of the depth profiles of major, minor, and trace element geochemistry. Concentrations of these elements in deep-sea sediments reflect the origin of those sediments and variations in sedimentation processes. Using the depth profile of the concentration of each element, the variation of the sediment lithology with geologic event may be estimated, and the sedimentation history can be read from the geochemistry.

2. Elucidation of regional differences between chemical constituents of deep-sea sediments of the Nankai

\footnotetext{
${ }^{1}$ Kagami, H., Karig, D. E., Coulbourn, W. T., et al., Init. Repts. DSDP, 87: Washington (U.S. Govt. Printing Office).

( Themistry, Faculty of Science, University of Tokyo, Hongo, Tokyo 113, Japan; (Matsumoto) Geological Institute, Faculty of Science, University of Tokyo, Hongo, Tokyo 113, Japan.
}

Table 1. Locations of Sites 294, 296, 297, 436, 439, 582,583 , and 584 .

\begin{tabular}{ccccc}
\hline & & & $\begin{array}{c}\text { Water } \\
\text { Septh } \\
(\mathrm{m})\end{array}$ & $\begin{array}{c}\text { Maximum } \\
\text { penetration } \\
(\mathrm{m})\end{array}$ \\
\hline 294 & $22^{\circ} 34.74^{\prime} \mathrm{N}$ & $131^{\circ} 23.13^{\prime} \mathrm{E}$ & 5784 & 118 \\
296 & $29^{\circ} 20.41^{\prime} \mathrm{N}$ & $133^{\circ} 31.52^{\prime} \mathrm{E}$ & 2920 & 1087 \\
297 & $30^{\circ} 52.36^{\prime} \mathrm{N}$ & $134^{\circ} 09.89^{\prime} \mathrm{E}$ & 4481 & 679.5 \\
436 & $39^{\circ} 55.96^{\prime} \mathrm{N}$ & $145^{\circ} 33.47^{\prime} \mathrm{E}$ & 5240 & 397.5 \\
439 & $40^{\circ} 37.61^{\prime} \mathrm{N}$ & $143^{\circ} 18.63^{\prime} \mathrm{E}$ & 1656 & 1157.5 \\
582 & $31^{\circ} 46.5^{\prime} \mathrm{N}$ & $133^{\circ} 54.8^{\prime} \mathrm{E}$ & 4879 & 749.4 \\
583 & $31^{\circ} 49.8^{\prime} \mathrm{N}$ & $133^{\circ} 51.3^{\prime} \mathrm{E}$ & 4634 & 450.0 \\
584 & $40^{\circ} 28.0^{\prime} \mathrm{N}$ & $143^{\circ} 57.1^{\prime} \mathrm{E}$ & 4078 & 954.0 \\
\hline & & & & \\
\hline
\end{tabular}

Trough and those of the Japan Trench, and the cause of such differences. Chemical compositions of the deepsea sediments near Japanese islands differ (Sugisaki, 1978, 1979, 1980a, 1980b; Minai, 1982). Sugisaki studied the geochemistry of modern deep-sea sediments in the Japan Sea, Japan Trench, and Shikoku Basin, using $\mathrm{X}$-ray fluorescence (XRF). In this chapter, we hope to clarify the differences in geochemical characteristics (particularly trace element-for example, REE-geochemistry) between the deep-sea sediments of the Nankai Trough and those of the Japan Trench, and to discuss the factors that govern such differences.

Because the analytical results from the deep-sea sediments from three Leg 87 sites are not alone sufficient to infer the origin of trench-fill and trench-slope sediments, we have also analyzed the sediment samples collected during the other legs in the West Philippine Basin (Site 294), Shikoku Basin (Sites 296 and 297), and on the outer slope of the Japan Trench (Site 436) and the terrace of the Japan Trench (Site 439) (Table 1; Fig. 1) (Sites 294297: Karig, Ingle, et al., 1975; Sites 436, 439: Scientific Party, 1980).

\section{METHODS}

Samples consisting of about $10 \mathrm{ml}$ of mud and mudstone were washed with distilled water to remove contaminants from seawater in the sediment column and then were dried moderately in air at ambient temperature. Sand and sandstone were excluded. Air-dried samples 


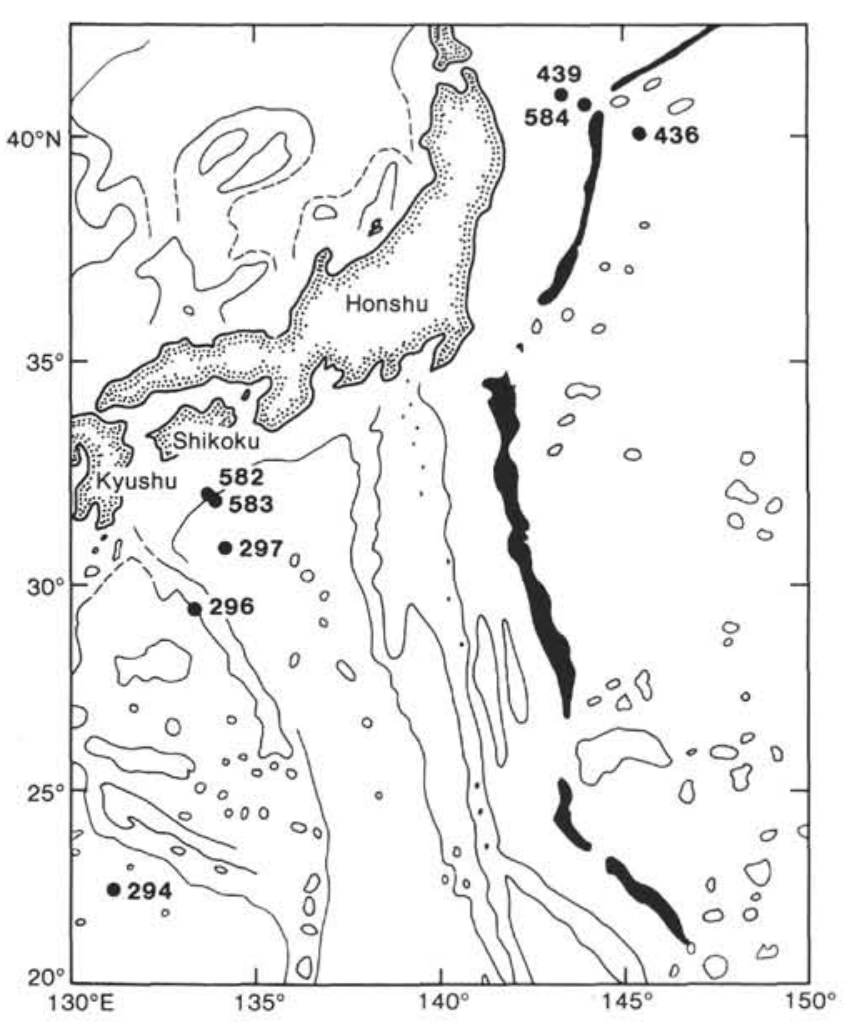

Figure 1. Locations of DSDP Sites 294, 296, 297, 436, 439, 582, 583, and 584 .

were finely pulverized for chemical analysis. Thirty-four major, minor, and trace elements in sediments were determined by means of $\mathrm{XRF}$ and instrumental neutron activation analysis (INAA).

\section{XRF Analytical Procedures}

A small piece $(1 \mathrm{~g})$ of the pulverized sample was mixed with $5 \mathrm{~g}$ of anhydrous lithium borate and melted to form a bead sample for determination of 10 major elements $(\mathrm{Si}, \mathrm{Ti}, \mathrm{Al}, \mathrm{Fe}, \mathrm{Mn}, \mathrm{Mg}, \mathrm{Ca}, \mathrm{Na}, \mathrm{K}$, P). Another $5 \mathrm{~g}$ of the sediment were pressed without any binder to prepare a disk sample for determinations of minor and trace elements ( $\mathrm{Co}, \mathrm{Cr}, \mathrm{Cu}, \mathrm{Ni}, \mathrm{Rb}, \mathrm{Sr}, \mathrm{V}, \mathrm{Zn}$, and $\mathrm{Zr}$ ). The bead and disk samples were analyzed with a Rigaku IKF-3064 dispersive XRF spectrometer. The analytical conditions were $50 \mathrm{kV} / 40 \mathrm{~mA}$ (Cu tube) for major elements and $70 \mathrm{kV} / 30 \mathrm{~mA}$ (W tube) for minor elements. More than 40 geologic standard rock samples were analyzed to prepare calibration curves for each element; GSJ rock standard JB-1 (basalt) was analyzed as a working standard to check analytical precision. The precision and reproducibility were reported previously (Matsumoto and Urabe, 1980).

\section{INAA Analytical Procedures}

A portion $(100 \mathrm{mg})$ of the pulverized sample was sealed in polyethylene film. The sealed samples, together with standard rocks, were irradiated for neutron activation in the TRIGA-II nuclear reactor at Rikkyo University. The irradiation conditions were as follows: thermal neutron flux, $1 \times 10^{12} \mathrm{n} /\left(\mathrm{cm}^{2} \cdot \mathrm{s}\right)$; irradiation time, 12-24 hr. After shorter-lived nuclides had decayed out, gamma-ray spectra were measured with either a $\mathrm{Ge}(\mathrm{Li})$ detector at the Radioisotope Center, University of Tokyo, or with an intrinsic pure Ge detector at the Laboratory for Earthquake Chemistry, University of Tokyo. On the basis of the specific activity, estimated from the peak area of each nuclide, the concentrations of 21 elements ( $\mathrm{Fe}, \mathrm{Na}, \mathrm{Ca}, \mathrm{Ba}, \mathrm{Co}, \mathrm{Cr}, \mathrm{Cs}, \mathrm{Hf}, \mathrm{Ni}$, $\mathrm{Sb}, \mathrm{Sc}, \mathrm{Ta}, \mathrm{Th}, \mathrm{U}, \mathrm{La}, \mathrm{Ce}, \mathrm{Sm}, \mathrm{Eu}, \mathrm{Tb}, \mathrm{Yb}$, and $\mathrm{Lu}$ ) were determined. The precision of each analysis was checked by analyzing the working standard at the same time. However, the precision was not always better than that obtained with XRF. Hence, XRF data are quoted in this report whenever determinations were made with both XRF and INAA.

\section{RESULTS}

\section{Nankai Trough}

Site 582 is situated in the southern Nankai Trough, about $135 \mathrm{~km}$ southeast of Shikoku. At Site 582, three holes were drilled down to $749.4 \mathrm{~m}$ sub-bottom. Quaternary sediments were collected down to $710 \mathrm{~m}$, and upper Pliocene sediments were found below $710 \mathrm{~m}$. The lithologic section was divided into two units according to the differences in sediment lithology (site chapter, Site 582 , this volume). Unit 1 (above $560 \mathrm{~m}$ ) is composed of thick alternations of turbiditic sand and mud, whereas Unit 2 (below $560 \mathrm{~m}$ ) is composed of hemipelagite. Percentages of major, minor, and trace elements in the sediments are listed in Table 2.

At Site 583, eight holes were drilled near the trench axis of the Nankai Trough to the west of Site 582 (site chapter, Site 583, this volume). Analyses by either XRF or INAA, or by both, were performed on 19 samples from Holes 583, 583B, 583D, 583F, and 583G (Table 2). The depth profiles for selected chemical constituents at Sites 582 and 583 are represented in Figure 2. The data for some REEs (Ce, Sm, Eu, Tb, and $\mathrm{Lu})$ are omitted because of the geochemical similarity among REEs.

\section{Site $\mathbf{5 8 2}$}

\section{Major Element Geochemistry}

The silica concentration in these sediments ranges from 62 to $69 \%$, which is higher than the biogenic silica content estimated by smear-slide observation and mineralogic studies (site chapter, Site 582, this volume). On the basis of X-ray diffraction study, we have determined that nonbiogenic silica components mainly represent quartz derived from terrigenous clastic sediment. The slight variation in silica concentration could be explained by variation in the mineral composition and the grain-size distribution of the sediments.

The chemical composition of deep-sea sediments at this site is rather homogeneous with respect to sub-bottom depth, except for some components, such as $\mathrm{CaO}$, $\mathrm{Fe}_{2} \mathrm{O}_{3}$ (total iron), and $\mathrm{MnO}$ (Fig. 2). The variation in the $\mathrm{CaO}$ concentration could be explained by the variation in the concentration of biogenic calcium carbonate. This explanation is supported by lithologic and mineralogic studies. The variation in $\mathrm{Fe}_{2} \mathrm{O}_{3}$ and $\mathrm{MnO}$ concentrations could reflect changes in sediment lithology. More geochemical results, together with lithologic and mineralogic data, are needed to clarify the factors that control these variations. Despite those slight changes, the chemical composition of turbiditic and hemipelagic mud is quite homogeneous.

\section{Minor and Trace Element Geochemistry}

Except for $\mathrm{Sr}, \mathrm{Ba}, \mathrm{Co}, \mathrm{Cr}, \mathrm{Cu}$, and $\mathrm{Ni}$, the concentrations of minor and trace elements are similar throughout the sediment column (Fig. 2). Concentrations of REEs such as La, a typical light REE (LREE), and Yb, a typical heavy REE, also remain nearly constant in Site 582 sediment (Fig. 3). The major-element oxides $\mathrm{CaO}$ or 
$\mathrm{MnO}$ or both are enriched at various depths, and the alkaline earths, $\mathrm{Sr}$ and $\mathrm{Ba}$, correlate with $\mathrm{CaO}$, whereas the other transition metals correlate with $\mathrm{MnO}$. This relationship implies that heavier alkaline earths exist mainly in biogenic carbonates, and that the other metals exist in hydrogenous manganese hydroxides. The concentrations and elemental ratios (e.g., La/Yb, Fig. 2) vary only slightly with sub-bottom depth.

\section{Site $\mathbf{5 8 3}$}

The chemical compositions of sediments at this site are almost homogeneous throughout the core, except for $\mathrm{CaO}$ and $\mathrm{Sr}$ concentrations (Table 2; Fig. 2). Fluctuations of these components are attributed primarily to variation in the concentration of biogenic carbonate.

Chemical compositions of the mud and mudstone at Site 583 are similar to those at Site 582 (Fig. 3), implying that the Quaternary turbiditic mud from Sites 582 and 583 as well as the upper Pliocene hemipelagite from Site 582 have a common origin, despite their lithologic differences.

\section{Philippine Sea and Shikoku Basin}

Site 294 is in the northern part of the western Philippine Basin; Sites 296 and 297 are in the Shikoku Basin to the south of the Nankai Trough (Table 1; Fig. 1). Site 297 is situated about $250 \mathrm{~km}$ north of Site 296. One sample from Site 294 (typical pelagic red clay), 9 samples from Site 296, and 3 samples from Site 297 were analyzed (Table 3; Figs. 4 and 5).

\section{Site 294}

The chemical composition of the deep-sea sediment collected from this site differs from that of the hemipelagic turbidite mud in the Nankai Trough. Concentrations of minor and trace elements are typical for pelagic sediments that have relatively high concentrations of transition metals. The REE pattern shows LREE enrichment with respect to chondrite (Fig. 5). This pattern (Fig. 5) is similar to patterns of other sediments near land (e.g., Fig. 3), except for the negative $\mathrm{Ce}$ anomaly.

The REE patterns are characteristic of various sediments deposited in marine environments (e.g., Piper, 1974). Shimizu and Masuda (1977) analyzed several cherts from DSDP cores and from subaerial samples. The REE pattern of the pelagic chert shows a negative $\mathrm{Ce}$ anomaly, which does not appear in the REE patterns of on-land cherts. Steinberg and his co-workers (Steinberg and Marin, 1978; Rangin et al., 1981; Steinberg et al., 1983) also discovered such a $\mathrm{Ce}$ anomaly in pelagic clays. These authors consider the $\mathrm{Ce}$ anomaly a fingerprint characteristic of sedimentation in open-ocean environments. Minai and his co-workers (Minai, 1982; Minai et al., in prep. ${ }^{3}$ ) analyzed about 30 deep-sea surface sediments in the Pacific Ocean. They showed that the $\mathrm{Ce}$ anomaly in the REE pattern of several sediments may be characteristic of pelagic sedimentation, and that the

\footnotetext{
${ }^{3}$ Minai, Y., Tominaga, T., Nakamura, Y., and Wakita, H., in preparation. Geochemistry of deep sea sediments in the Pacific.
}

magnitude of the Ce anomaly correlates well with the latitude of the station and the distance from spreading centers. Considering $\mathrm{Ce}$ and $\mathrm{Mn}$ contents, as well as deepsea sediment accumulation rates in the western Pacific Ocean, Matsumoto and others (in press) proposed a hydrothermal origin of the $\mathrm{Ce}$ anomaly in pelagic sediments.

Our results on the sample from Site 294 agree with the previous observations: the Ce anomaly of Site 294 sediments can be attributed to the hydrothermal activity in the West Philippine Basin. We analyzed only one sample from Site 294, however, and more extensive study is needed to confirm the existence and magnitude of a $\mathrm{Ce}$ anomaly at that location.

\section{Site 296}

\section{Major Element Geochemistry}

Site 296 sediments are characterized by high $\mathrm{CaO}$ concentrations ranging from 15.9 to $36.3 \%$ (Table 3 ). $\mathrm{CaO}$ is present mainly in the biogenic-carbonate sediments. Considering the amounts of ignition loss, we estimate that these samples contain about $10 \%$ or more $\mathrm{CO}_{2}$ as carbonate.

The concentrations of major-element oxides $\mathrm{TiO}_{2}$, $\mathrm{Al}_{2} \mathrm{O}_{3}, \mathrm{Na}_{2} \mathrm{O}$, and $\mathrm{K}_{2} \mathrm{O}$ decrease gradually downhole, as does $\mathrm{SiO}_{2}$, after an abrupt decrease in the first $100 \mathrm{~m}$ sub-bottom. In the upper part of the section, chemical compositions resemble those of terrestrial shales or nearshore sediments like those of Sites 582 and 583, whereas in the lower part of the stratigraphic section, compositions resemble those of pelagic sediments like those of Site 294. These variations suggest that the contribution of terrigenous sediment is much higher in the upper zone. The Nankai Trough sediments (Sites 582 and 583) are similar in chemistry to shales and are classified as hemipelagites. The Shikoku Basin sediments are typical pelagic clay. The horizontal movement of Site 296 by plate motion probably explains the chemical variations. The deeper layer of the sediment column accumulated at a southerly position within the pelagic sediment zone. As the Philippine Sea Plate moved to the north and Site 296 reached the zone of hemipelagic sedimentation, the character of the sediments changed gradually from pelagic to hemipelagic.

\section{Minor and Trace Element Geochemistry}

Barium increases in the lower zone, where Hf, Ta, and REEs decrease very slightly. Other elements show no clear change with depth.

The REE patterns change systematically with subbottom depth (Fig. 5). The REE patterns of the sediments in the upper zone at Site 296 (Fig. 5) are similar to those for Sites 582 and 583 (Fig. 3); LREE are enriched and there is no Ce anomaly. REE patterns of the sediments in the lower zone are similar to those of the pelagic sediment from Site 294; they show less enrichment of LREE and a Ce anomaly. These relationships in REE pattern are attributed to plate motion.

Sample 296-13-3, 50-52 cm shows an exceptionally positive Ce anomaly that could be explained by incorporation of Mn hydroxides, because manganese nodules 
Table 2. Sites 582 and 583: concentrations of major-element oxides (wt.\%) and minor and trace elements (ppm) in deep-sea sediments.

\begin{tabular}{|c|c|c|c|c|c|c|c|c|c|c|c|c|c|c|}
\hline $\begin{array}{l}\text { Hole-Core-Section } \\
\text { (interval in cm) }\end{array}$ & $\begin{array}{l}\text { Sub-bottom } \\
\text { depth }(\mathrm{m})\end{array}$ & $\mathrm{SiO}_{2}$ & $\mathrm{TiO}_{2}$ & $\mathrm{Al}_{2} \mathrm{O}_{3}$ & $\mathrm{Fe}_{2} \mathrm{O}_{3}{ }^{\mathrm{a}}$ & $\mathrm{MnO}$ & $\mathrm{MgO}$ & $\mathrm{CaO}$ & $\mathrm{Na}_{2} \mathrm{O}$ & $\mathrm{K}_{2} \mathrm{O}$ & $\mathrm{P}_{2} \mathrm{O}_{5}$ & $\mathrm{Ba}$ & Co & $\mathrm{Cr}$ \\
\hline $582-1-1,52-54$ & 0.53 & 66.6 & 0.72 & 16.6 & 6.43 & 0.12 & 2.80 & 1.40 & 2.19 & 3.06 & 0.06 & 584 & 19 & 73 \\
\hline $582 \mathrm{~B}-2-2,134-136$ & 62.55 & 63.9 & 0.78 & 17.4 & 7.28 & 0.13 & 2.78 & 2.60 & 1.95 & 3.15 & 0.09 & & 15 & 85 \\
\hline $582 \mathrm{~B} 3-2,120-122$ & 70.61 & & & & & & & & & & & 524 & & \\
\hline $582 \mathrm{~B}-23-2,40-42$ & 262.61 & 64.8 & 0.77 & 17.3 & 6.89 & 0.12 & 2.81 & 1.91 & 2.13 & 3.12 & 0.12 & 542 & 15 & 82 \\
\hline $582 \mathrm{~B}-26-2,39-43$ & 291.41 & 65.1 & 0.76 & 16.5 & 6.83 & 0.12 & 2.75 & 2.74 & 2.07 & 3.07 & 0.08 & & 15 & 97 \\
\hline $582 \mathrm{~B}-40-2,40-42$ & 424.51 & 64.0 & 0.81 & 18.1 & 7.24 & 0.15 & 2.15 & 2.22 & 1.72 & 3.13 & 0.08 & 494 & 17 & 109 \\
\hline 582B-52-3, 126-127 & 541.27 & 66.8 & 0.73 & 16.1 & 6.33 & 0.13 & 2.55 & 2.32 & 2.24 & 2.75 & 0.09 & 569 & 15 & 83 \\
\hline 582B-60-2, 38-39 & 615.99 & 65.2 & 0.79 & 17.4 & 7.86 & 0.12 & 2.60 & 1.14 & 1.65 & 3.23 & 0.05 & 605 & 32 & 91 \\
\hline $582 \mathrm{~B}-62-3,68-69$ & 636.99 & 66.7 & 0.74 & 17.2 & 6.05 & 0.09 & 2.56 & 1.48 & 1.99 & 3.15 & 0.03 & & 13 & 79 \\
\hline 582B-68-2, 39-41 & 693.10 & 62.3 & 0.72 & 17.0 & 6.99 & 0.24 & 2.80 & 5.17 & 1.63 & 3.07 & 0.12 & & 15 & 82 \\
\hline 582B-71-1, 95-96 & 721.25 & 64.5 & 0.76 & 17.5 & 6.82 & 0.15 & 2.74 & 2.36 & 1.71 & 3.46 & 0.06 & 685 & 16 & 96 \\
\hline $583-1-1,57-58$ & 0.58 & 63.0 & 0.73 & 16.2 & 6.4 & 0.10 & 2.43 & 1.8 & 2.4 & 2.8 & 0.04 & & 13 & 65 \\
\hline $583-4-4,56-57$ & 28.06 & 64.8 & 0.74 & 16.5 & 7.0 & 0.11 & 2.7 & 2.6 & 2.6 & 2.9 & 0.06 & & 16 & 79 \\
\hline $583-7-1,20-21$ & 46.11 & 61.8 & 0.79 & 17.8 & 8.0 & 0.13 & 3.3 & 3.6 & 1.9 & 2.6 & 0.06 & & 20 & 69 \\
\hline $583-11-1,57-58$ & 74.08 & 64.7 & 0.77 & 17.1 & 7.0 & 0.11 & 2.7 & 2.4 & 2.0 & 3.0 & 0.06 & & 17 & 75 \\
\hline $583-17-1,40-41$ & 107.41 & 66.6 & 0.73 & 16.4 & 6.6 & 0.11 & 2.5 & 2.2 & 1.9 & 2.9 & 0.04 & & 16 & 94 \\
\hline $583-23-1,77-78$ & 135.78 & 66.1 & 0.68 & 15.5 & 6.7 & 0.11 & 2.4 & 3.9 & 2.0 & 2.5 & 0.07 & & 13 & 80 \\
\hline $583 F-6-1,27-29$ & 198.98 & 64.5 & 0.75 & 17.1 & 7.2 & 0.12 & 2.9 & 2.5 & 2.0 & 2.9 & 0.06 & & 14 & 64 \\
\hline $583 F-8-1,39-41$ & 218.10 & 65.6 & 0.79 & 17.4 & 6.7 & 0.10 & 2.7 & 2.0 & 1.8 & 3.0 & 0.05 & & 16 & 86 \\
\hline $583 F-11-1,112-114$ & 247.73 & 66.2 & 0.7 & 15.9 & 6.7 & 0.12 & 2.7 & 3.1 & 2.1 & 2.4 & 0.09 & & 13 & 68 \\
\hline $583 \mathrm{~F}-15-1,35-37$ & 285.76 & 65.4 & 0.7 & 16.7 & 6.6 & 0.12 & 2.5 & 3.1 & 2.2 & 2.6 & 0.04 & & 17 & 58 \\
\hline $583 F-18-1,78-79$ & 314.99 & 66.3 & 0.7 & 16.6 & 0.4 & 0.11 & 2.5 & 2.2 & 2.1 & 2.8 & 0.03 & & & \\
\hline $583 F-22-1,111-113$ & 354.02 & 65.2 & 0.7 & 17.1 & 6.6 & 0.12 & 2.8 & 2.2 & 2.2 & 2.9 & 0.05 & & & \\
\hline $583 F-26-1,124-125$ & 392.75 & 63.9 & 0.8 & 17.0 & 7.6 & 0.14 & 3.0 & 2.4 & 2.0 & 3.1 & 0.05 & & & \\
\hline $583 \mathrm{~F}-29-1,20-22$ & 420.61 & 65.5 & 0.78 & 16.7 & 6.7 & 0.13 & 2.9 & 2.0 & 2.3 & 2.9 & 0.04 & & & \\
\hline $583 \mathrm{G}-3-4,47-48$ & 330.88 & 64.7 & 0.80 & 17.1 & 7.2 & 0.11 & 2.9 & 1.9 & 1.9 & 3.1 & 0.42 & 543 & 14 & 95 \\
\hline $583 G-10-3,25-27$ & 397.06 & 65.9 & 0.76 & 17.1 & 6.6 & 0.11 & 2.5 & 2.0 & 1.7 & 3.2 & 0.31 & 553 & 17 & 92 \\
\hline 583B-3-2, 33-34 & 11.84 & 65.2 & 0.77 & 16.6 & 7.4 & 0.27 & 2.7 & 1.7 & 2.4 & 2.9 & 0.08 & & 13 & 90 \\
\hline $583 D-14-3,65-67$ & 175.66 & 61.8 & 0.78 & 17.9 & 8.4 & 0.13 & 2.8 & 3.7 & 1.8 & 2.7 & 0.12 & 430 & 19 & 76 \\
\hline $583 \mathrm{D}-20-1,38-40$ & 230.29 & 65.8 & 0.74 & 16.5 & 6.5 & 0.10 & 2.6 & 2.9 & 2.4 & 2.5 & 0.09 & 507 & 16 & 81 \\
\hline
\end{tabular}

Note: Blank: not analyzed.

a Total iron as $\mathrm{Fe}_{2} \mathrm{O}_{3}$.

often show positive Ce anomalies (e.g., Piper, 1974). Another explanation relies on the selective partitioning and redistribution of $\mathrm{Ce}$ induced by the oxidation of $\mathrm{Ce}$ after burial. Matsumoto and others (in press) have suggested that $\mathrm{Ce}$ depletion is an indicator for hydrothermal interactions in the sediment layer, an anomaly produced by oxidation of $\mathrm{Ce}^{3+}$ to $\mathrm{Ce}^{4+}$. In this case, $\mathrm{Ce}^{3+}$ and $\mathrm{Ce}^{4+}$ would coexist in the sediment column in contact with hydrothermal water. Because the chemical properties of $\mathrm{Ce}^{4+}$ are different from those of $\mathrm{Ce}^{3+}$, hydrothermal interaction through oxidation-partitioning may differentiate and redistribute $\mathrm{Ce}$ in the sediment column.

\section{Site 297}

Chemical compositions of Site 297 sediments are similar to those of the Nankai Trough sediments (Sites 582 and 583) and to those of the upper Site 296 sediments, except that $\mathrm{CaO}$ concentrations at Site 296 are much higher. This similarity extends to the minor and trace element geochemistry (compare the analytical results listed in Tables 2 and 3).

\section{Summary: Geochemistry of Sediments from the Philippine Sea to the Nankai Trough}

The modern sediments at Site 294 are typical pelagic clay; their REE pattern shows a negative Ce anomaly, typical of pelagic sediment influenced by hydrothermal activity. To the north, the character of the deep-sea sediments changes from typical pelagic sediment at Site 294 to the hemipelagite at Sites 582 and 583. Such regional variations in geochemistry are also recognized in the vertical variation at Site 296. As for the REE geochemistry, the Ce anomaly diminishes with decreasing sub-bottom depth, a variation explicable in terms of plate motion. The deeper layer of the sediment column accumulated to the south of the present site, in a zone of pelagic sedimentation; and the upper layer accumulated near the present site, within the zone of hemipelagic sedimentation. In contrast to Site 296 sediment, vertical variation of the Ce anomaly is not observed in Site 297 sediment. Site 297 is situated to the north of Site 296 , and the age of the recovered sediment column is younger than at Site 297. These facts suggest that the lithologic section recovered at Site 297 is too short to reach layers accumulated earlier, beneath the zone of pelagic sedimentation.

Deep-sea sediments can be classified into ridge sediment, pelagic sediment, and offshore sediment, on the basis of their Mn concentrations, sediment accumulation rates, and REE patterns (Matsumoto et al., in press). In that classification, the sediment at Site 294 is pelagic, and that at Sites 297, 582, and 583 is offshore. Drilling at Site 296 penetrated pelagic sediments at the lower levels and offshore sediments at the upper levels; this change in sedimentary environments was caused by plate motion.

\section{Japan Trench}

Site 584 is on the landward slope of the Japan Trench off Sanriku, northeastern Japan. A 954-m sediment column was recovered from this site. Site 584 sediments are composed mainly of siliceous mud and mudstone with 
Table 2. (Continued).

\begin{tabular}{|c|c|c|c|c|c|c|c|c|c|c|c|c|c|c|c|c|c|c|c|c|}
\hline Cs & $\mathrm{Cu}$ & $\mathrm{Hf}$ & $\mathrm{Ni}$ & $\mathbf{R b}$ & $\mathrm{Sb}$ & $\mathrm{Sc}$ & $\mathrm{Sr}$ & $\mathrm{Ta}$ & Th & $\mathbf{U}$ & $\mathrm{V}$ & $\mathrm{Zn}$ & $\mathrm{Zr}_{\mathrm{r}}$ & $\mathrm{La}$ & $\mathrm{Ce}$ & $\mathrm{Sm}$ & $\mathrm{Eu}$ & $\mathrm{Tb}$ & $\mathrm{Yb}$ & Lu \\
\hline \multirow[t]{2}{*}{6.0} & 68 & 3.4 & 45 & 110 & 0.51 & 15 & 150 & 0.52 & 9.4 & 1.4 & 95 & 114 & 143 & 26.6 & 51 & 5.04 & 1.05 & 0.59 & 3.2 & 0.51 \\
\hline & 54 & & 55 & 107 & & & 125 & & & & 104 & 105 & 133 & 29.1 & 54 & 5.57 & & 0.77 & 4.0 & 0.57 \\
\hline 5.5 & & 3.5 & & & 0.27 & 15 & & 0.52 & 9.3 & 1.3 & & & & 26.5 & 48 & 4.92 & 1.05 & 0.57 & 2.9 & 0.44 \\
\hline \multirow[t]{2}{*}{6.3} & 88 & 3.3 & 52 & 104 & 0.38 & 16 & 160 & 0.52 & 9.7 & 1.4 & 96 & 115 & 140 & 26.8 & 51 & 5.26 & 1.08 & 0.60 & 3.5 & 0.52 \\
\hline & 72 & & 60 & 105 & & & 181 & & & & 103 & 106 & 152 & 29.4 & 58 & 5.52 & & 0.80 & 3.5 & 0.50 \\
\hline 6.6 & 36 & 3.8 & 64 & 116 & 0.46 & 14 & 152 & 0.67 & 11.6 & 1.4 & 96 & 109 & 155 & 32.3 & 61 & 5.89 & 1.14 & 0.70 & 3.5 & 0.52 \\
\hline 4.6 & 40 & 3.8 & 43 & 93 & 0.37 & 15 & 192 & 0.45 & 8.7 & 1.2 & 100 & 89 & 161 & 25.3 & 48 & 5.04 & 1.09 & 0.54 & 3.3 & 0.49 \\
\hline \multirow[t]{3}{*}{6.6} & 165 & 3.7 & 91 & 119 & & 15 & 128 & 0.60 & 10.3 & 1.3 & 111 & 114 & 145 & 30.3 & 56 & 5.42 & 1.06 & 0.64 & 3.3 & 0.47 \\
\hline & 85 & & 50 & 114 & & & 149 & & & & 91 & 114 & 153 & 28.6 & 53 & 5.03 & & 0.78 & 3.1 & 0.47 \\
\hline & 90 & & 66 & 107 & & & 238 & & & & 96 & 111 & 131 & 29.0 & 52 & 5.30 & & 0.74 & 3.8 & 0.50 \\
\hline \multirow[t]{11}{*}{7.7} & 95 & 3.8 & 59 & 127 & 0.67 & 16 & 165 & 0.63 & 11.7 & 1.5 & 96 & 126 & 142 & 33.9 & 59 & 5.77 & 1.18 & 0.73 & 3.4 & 0.52 \\
\hline & 35 & & 18 & 97 & & & 170 & & & & 98 & 101 & 164 & & & & & & & \\
\hline & 54 & & 32 & 96 & & & 179 & & & & 98 & 123 & 142 & & & & & & & \\
\hline & 63 & & 23 & 78 & & & 198 & & & & 105 & 114 & 118 & & & & & & & \\
\hline & 44 & & 33 & 104 & & & 175 & & & & 104 & 112 & 144 & & & & & & & \\
\hline & 32 & & 37 & 104 & & & 172 & & & & 100 & 161 & 159 & & & & & & & \\
\hline & 36 & & 22 & 85 & & & 228 & & & & 89 & 132 & 134 & & & & & & & \\
\hline & 52 & & 25 & 95 & & & 180 & & & & 100 & 109 & 137 & & & & & & & \\
\hline & 49 & & 37 & 108 & & & 165 & & & & 104 & 120 & 159 & & & & & & & \\
\hline & 42 & & 20 & 79 & & & 212 & & & & 98 & 123 & 131 & & & & & & & \\
\hline & 51 & & 20 & 85 & & & 220 & & & & 98 & 98 & 137 & & & & & & & \\
\hline 6.0 & 58 & 3.5 & 50 & 104 & 0.46 & 15 & 183 & 0.62 & 10.2 & 1.3 & 105 & 108 & 119 & 27.8 & 52 & 5.22 & 1.09 & 0.85 & 2.8 & 0.53 \\
\hline \multirow[t]{2}{*}{7.1} & 70 & 6.0 & 64 & 117 & 0.50 & 15 & 167 & 0.61 & 11.2 & 1.3 & 103 & 152 & 148 & 30.5 & 57 & 5.37 & 1.16 & 0.98 & 3.2 & 0.48 \\
\hline & 39 & & 48 & 100 & & & 146 & & & & 98 & 100 & 137 & & & & & & & \\
\hline 4.9 & 95 & 2.8 & 48 & 80 & 0.34 & 19 & 196 & 0.41 & 7.4 & 1.3 & 99 & 107 & 115 & 21.0 & 42 & 4.78 & 1.09 & 0.74 & 2.9 & 0.52 \\
\hline 4.2 & 47 & 3.6 & 47 & 81 & 0.27 & 15 & 210 & 0.45 & 7.6 & 1.1 & 101 & 90 & 155 & 22.5 & 43 & 4.53 & 1.01 & 0.77 & 2.9 & 0.45 \\
\hline
\end{tabular}

sporadic thin interlayers of sand and ash. The age of cores from this site ranges from the middle Miocene to the Quaternary.

\section{Site $\mathbf{5 8 4}$}

\section{Major Element Geochemistry}

Silica concentrations range from 67 to $88 \%$ (Table 4; Fig. 6), higher than at Sites 582 and 583, and the variation is somewhat larger than that in the sediments from the Nankai Trough. The high silica concentration reflects the sediment lithology, indicating that biogenic silica contributes largely to the total silica component.

In the upper $530 \mathrm{~m}$ of the sediment column, silica concentration exceeds $75 \%$, except in the Quaternary sandy mud at the top of the hole. Between 530 and 760 $\mathrm{m}$, silica concentration is lower. Farther downhole, concentrations again increase to values comparable to those in the upper, high-silica zone (Fig. 6). These changes correlate with the sediment accumulation rates. The accumulation rate is about $100 \mathrm{~m} / \mathrm{Ma}$ in the upper, high-silica zone, $20 \mathrm{~m} / \mathrm{Ma}$ in the middle, low-silica zone, and $100 \mathrm{~m} / \mathrm{Ma}$ in the lower, high-silica zone (site chapter, Site 584 , this volume). The incorporation of biogenic silica into the sediment increases the silica content and the accumulation rate. The biogenic silica component is high in the high-silica zones and low in the low-silica zones, where silica might be derived from terrigenous clastics. The fact that chemical compositions of the sediments in the low-silica zone are similar to those of transitional shale supports this explanation.
Unlike the $\mathrm{SiO}_{2}$ concentration, the $\mathrm{CaO}$ concentration varies randomly. Calcium is contained in terrigenous clastics, such as feldspars and clay minerals, and in biogenic carbonates. The concentrations of $\mathrm{Na}_{2} \mathrm{O}$ and $\mathrm{K}_{2} \mathrm{O}$, which are contained mainly in feldspars and clay minerals, are nearly constant, indicating a constant contribution of terrigenous clastics throughout the core. Thus, the random fluctuation of $\mathrm{CaO}$ concentration could be explained by the variable contribution of biogenic carbonates.

Manganese, a sensitive indicator of the hydrogenous contribution, is extremely enriched at some horizons in the core (Matsumoto et al., in press).

Other major element abundances, except for total iron, are relatively constant throughout the core. Iron concentration is, on the whole, negatively correlated with silica concentration (Fig. 6), meaning that iron is not contained in biogenic silica components, but is contained mainly in terrigenous clastics.

\section{Minor and Trace Element Geochemistry}

Strontium concentration correlates excellently with $\mathrm{CaO}$ concentration, implying that $\mathrm{Sr}$ is contained mainly in $\mathrm{CaO}$-bearing phases like biogenic calcium carbonate. The other alkaline earth, $\mathrm{Ba}$, does not correlate with either $\mathrm{CaO}$ or Sr. Barium concentrations are variable in the zone from 30 to $120 \mathrm{~m}$ and enriched below $300 \mathrm{~m}$ sub-bottom depth (Fig. 6). Because barium is a kind of large-ion lithophile (LIL), it does not always behave like other lighter alkaline earths in geochemical processes. In volcanic rocks, Ba correlates with other LILs such as 


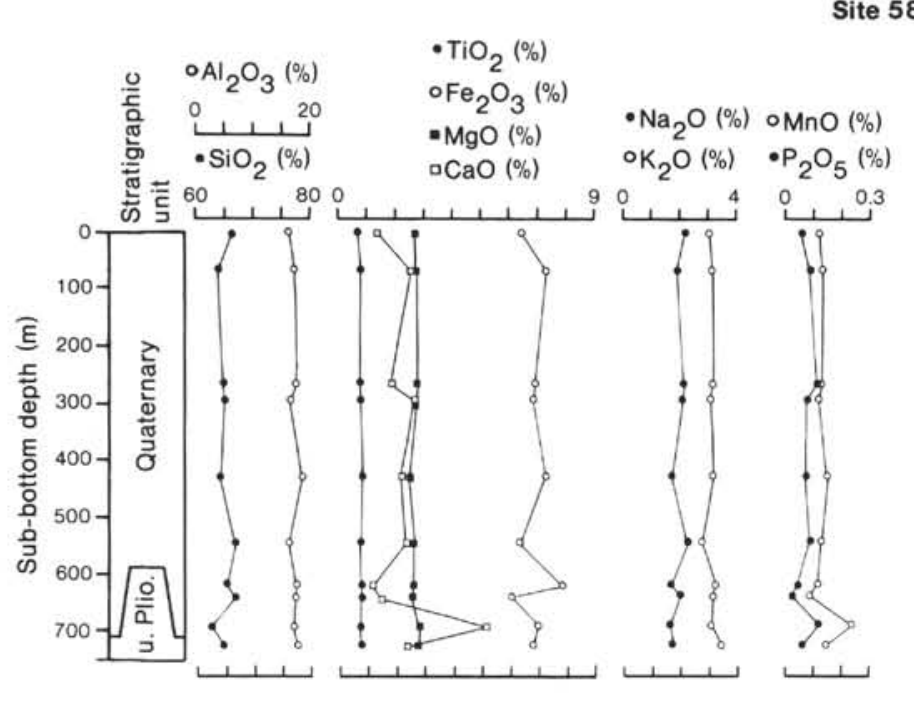

Site 582
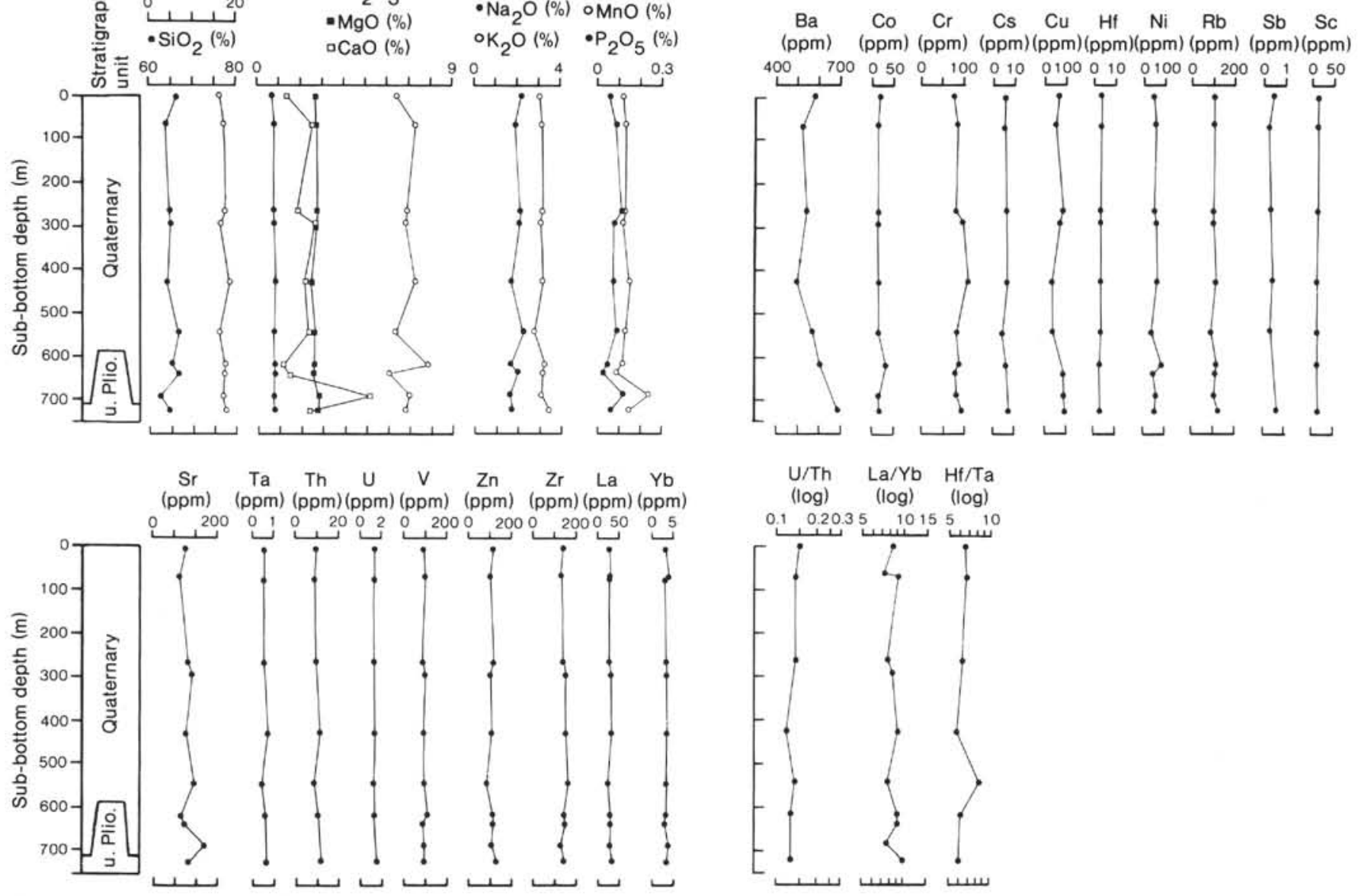

Site $\mathbf{5 8 3}$
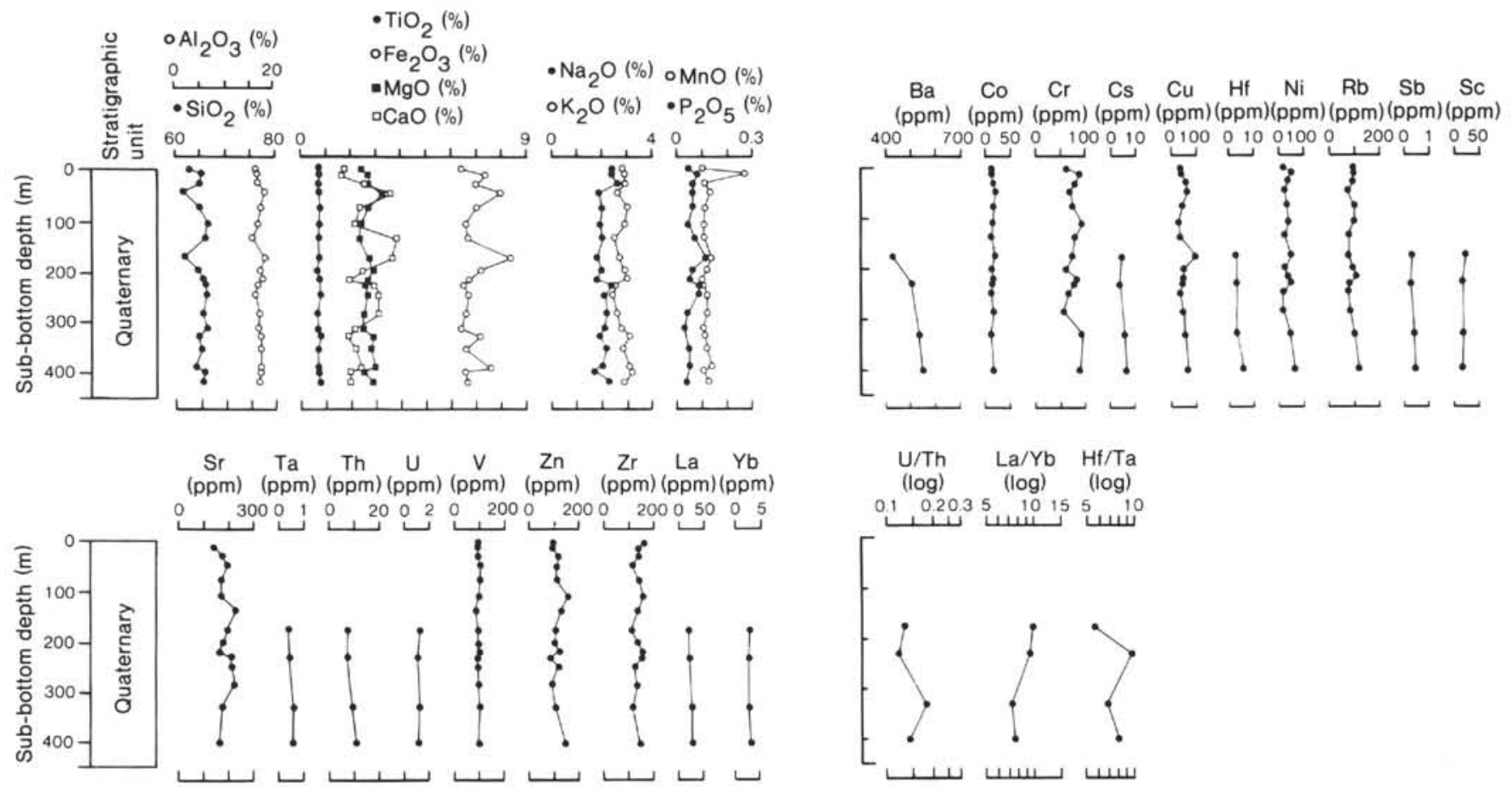

Figure 2. Depth profiles for concentrations of major, minor, and trace elements in deep-sea sediments from Sites 582 and 583. 


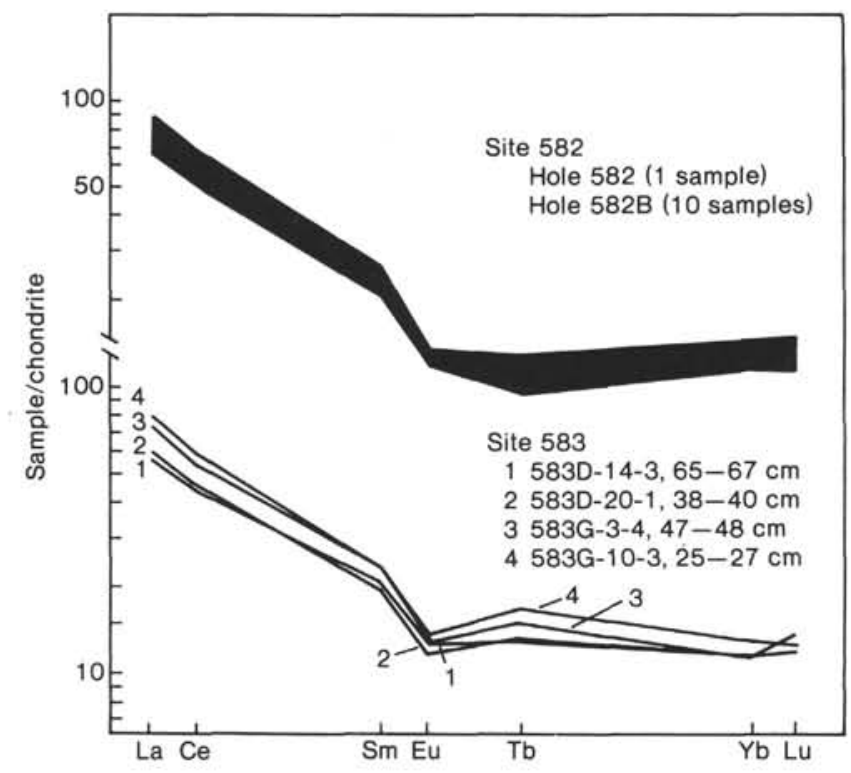

Figure 3. Typical chondrite-normalized rare-earth-element patterns for deep-sea sediments from Sites 582 and 583.

Cs, REEs, U, and Th. The LILs (Cs, Hf, Ta, Th, and REEs) are slightly enriched in the lower zone of the Site 584 lithologic section (Table 4). In the zone below $300 \mathrm{~m}$, barium would behave mainly as the other LILs, and would be contained mainly in LIL-bearing phases. These LILs are not enriched in the upper, Ba-bearing zone, suggesting that $\mathrm{Ba}$ is contained in barite in this upper zone. Gurvich and others (1978) found an excellent correlation between $\mathrm{Ba}$ and barite concentration in pelagic sediments. In fact, barite nodules were found in several horizons at shallow levels.

Geochemistry of LILs in deep-sea sediments provides an excellent key to the origin and diagenetic alteration of the sediments. As mentioned, most LILs are slightly enriched in the lithologic section below about $400 \mathrm{~m}$. The depth profile of $U$ has almost no trend; it has only a very slight enrichment in the upper few samples. Most of the LILs in deep-sea sediments seem to be contained in silicates and in other accessory minerals derived from terrigenous clastic sediments, and LIL concentrations are expected to correlate positively with the total iron but negatively with $\mathrm{SiO}_{2}$ (biogenic silica). These correlations were not observed in our data, perhaps because the changes were of such small magnitude. The REEs could be derived mainly from terrigenous clastics in this core, because the chondrite-normalized REE patterns show an LREE enrichment as in shales (Fig. 7).

The difference in LIL concentrations between the upper and lower zones suggests a change of sediment provenance. The LIL geochemistry changes in the uppermost Miocene sediments, a change also confirmed by the other geochemical parameters, such as the ratios U/ $\mathrm{Th}$ and $\mathrm{La} / \mathrm{Yb}$ (Fig. 6). The $\mathrm{La} / \mathrm{Yb}$ ratio represents the REE pattern. The ratio between elements was not affected by changing concentrations of other components. These ratios also change in the middle of the core, confirming our previous explanation regarding the change of LIL concentrations. The REE patterns also confirm the change of the source for terrigenous clastics (Fig. 7); lighter REEs are more enriched in the lower zone.

\section{Site 439}

Site 439 is situated on the deep-sea terrace near Site 584 (Fig. 1). Cretaceous black shale recovered at the bottom of the core might represent an open-ocean pelagic deposit now accreted to the northeastern Japan arc in the course of subduction of the Pacific Plate (von Huene et al., 1982). The chemical compositions of these shales (Table 5), however, are quite similar to those of Miocene to Pliocene hemipelagic mud at Site 584 (Table 4). This similarity suggests that the black shale was not part of the accretionary prism but was also deposited in its present setting.

\section{North Pacific Ocean}

\section{Site 436}

Site 436 is situated on the outer slope of the Japan Trench about $150 \mathrm{~km}$ east of Site 584 (Scientific Party, 1980). Site 436 sediments include Quaternary, Pliocene, and Miocene siliceous mud and mudstone, Oligocene brown clay, and Cretaceous brown clay and chert. The analytical results are listed in Table 6 and are plotted in Figure 8.

\section{Major Element Geochemistry}

It is remarkable that concentrations of major elements in the Quaternary, Pliocene, and upper Miocene sediments at Site 436 are similar to those of Site 584 sediments. Such a high degree of similarity may mean that trench inner-slope and outer-slope sediments cannot be distinguished by their geochemistry. Most of the Miocene, Oligocene, and Cretaceous sediments show extremely high $\mathrm{MnO}$ concentrations.

\section{Minor and Trace Element Geochemistry}

The concentrations of LIL elements and their ratios (like U/Th) change slightly at the Miocene/Pliocene boundary at this site and Site 584 (Figs. 6, 8). At both locations, LIL (except U) concentrations and Hf/Ta, U/ $\mathrm{Th}$, and $\mathrm{La} / \mathrm{Yb}$ ratios increase in the lower sediments. This change suggests that the source of sediment supplied to the ocean margin near the Japan Trench changed at the Miocene/Pliocene boundary.

The REE patterns for Site 436 sediments (Fig. 9) show a negative $\mathrm{Ce}$ anomaly for the Cretaceous chert. These Ce-depleted sediments always contain larger amounts of $\mathrm{Co}, \mathrm{Cu}$, and other transition elements common in metalliferous sediments near spreading centers, suggesting that hydrothermal activity is responsible for the $\mathrm{Ce}$ anomaly in these sediments.

To summarize, the chemistry of the Quaternary, Pliocene, and upper Miocene sediments at Site 436 resembles that of Site 584 sediments, whereas the chemistry of the middle Miocene to Cretaceous sediments at Site 436 differs from that of overlying sediment at that site and from that of Site 584 sediments. The LIL concentrations, their ratios, and REE patterns appears to change 
Table 3. Sites 294, 296, and 297: concentrations of major-element oxides (wt. \%) and minor and trace elements (ppm) in deep-sea sediments.

\begin{tabular}{|c|c|c|c|c|c|c|c|c|c|c|c|c|c|c|}
\hline $\begin{array}{l}\text { Hole-Core-Section } \\
\text { (interval in } \mathrm{cm} \text { ) }\end{array}$ & $\begin{array}{l}\text { Sub-bottom } \\
\text { depth (m) }\end{array}$ & $\mathrm{SiO}_{2}$ & $\mathrm{TiO}_{2}$ & $\mathrm{Al}_{2} \mathrm{O}_{3}$ & $\mathrm{Fe}_{2} \mathrm{O}_{3}{ }^{\mathrm{a}}$ & $\mathrm{MnO}$ & $\mathrm{MgO}$ & $\mathrm{CaO}$ & $\mathrm{Na}_{2} \mathrm{O}$ & $\mathrm{K}_{2} \mathrm{O}$ & $\mathrm{P}_{2} \mathrm{O}_{5}$ & $\mathrm{Ba}$ & Co & $\mathrm{Cr}$ \\
\hline $296-1-2,117-119$ & 2.68 & 45.29 & 0.49 & 12.17 & 4.99 & 0.12 & 2.05 & 17.98 & 1.26 & 2.30 & 0.04 & & 11 & 42 \\
\hline $296-6-3,50-52$ & 48.01 & 41.92 & 0.35 & 10.00 & 3.65 & 0.13 & 1.26 & 22.62 & 1.49 & 2.20 & 0.01 & & 5 & 25 \\
\hline $296-6-3,78-80$ & 48.29 & 49.93 & 0.36 & 11.82 & 3.94 & 0.11 & 1.32 & 15.92 & 2.22 & 2.40 & 0.02 & & 8 & 18 \\
\hline $296-9-2,50-52$ & 75.01 & 35.46 & 0.34 & 9.45 & 3.69 & 0.12 & 1.31 & 28.59 & 1.20 & 2.04 & 0.03 & 538 & 10 & 27 \\
\hline $296-13-3,50-52$ & 114.51 & 31.90 & 0.23 & 7.83 & 2.71 & 0.12 & 0.65 & 34.29 & 1.37 & 1.62 & 0.05 & & 4 & 23 \\
\hline $296-19-3,28-30$ & 171.29 & 35.05 & 0.32 & 9.45 & 3.73 & 0.10 & 1.46 & 27.27 & 1.27 & 2.04 & 0.08 & & 9 & 25 \\
\hline $296-25-3,39-41$ & 228.40 & 28.91 & 0.21 & 7.05 & 2.55 & 0.17 & 0.63 & 36.24 & 0.85 & 1.46 & 0.04 & 900 & 10 & 21 \\
\hline $296-31-5,100-102$ & 289.01 & 29.37 & 0.19 & 6.56 & 2.77 & 0.26 & 0.63 & 36.33 & 0.73 & 1.44 & 0.06 & 1065 & 14 & 15 \\
\hline $296-46-4,105-107$ & 430.06 & 31.05 & 0.21 & 7.09 & 4.00 & 0.36 & 1.24 & 34.20 & 1.25 & 0.93 & 0.07 & & 8 & \\
\hline $297-4-4,69-71$ & 44.2 & 63.5 & 0.75 & 16.8 & 6.29 & 0.23 & 2.81 & 4.49 & 1.81 & 3.34 & 0.04 & & 15 & 7.8 \\
\hline $297-8-4,30-32$ & 110.31 & 64.7 & 0.76 & 17.3 & 6.73 & 0.21 & 3.03 & 2.08 & 1.85 & 3.30 & 0.04 & & 22 & 83 \\
\hline $297-14-3,50-52$ & 318.01 & 63.5 & 0.79 & 18.6 & 8.02 & 0.18 & 2.91 & 0.67 & 1.67 & 3.63 & n.d. & & 21 & 93 \\
\hline $294-3-3,30-32$ & 77.31 & & & & & & & & & & & 250 & & \\
\hline
\end{tabular}

Note: Blank: not analyzed; n.d.: not detected.

${ }^{\mathrm{a}} \mathrm{Total}$ iron as $\mathrm{Fe}_{2} \mathrm{O}_{3}$.

Table 4. Site 584: concentrations of major-element oxides (wt.\%) and minor and trace elements (ppm) in deep-sea sediments.

\begin{tabular}{|c|c|c|c|c|c|c|c|c|c|c|c|c|c|c|}
\hline $\begin{array}{l}\text { Hole-Core-Section } \\
\text { (interval in } \mathrm{cm} \text { ) }\end{array}$ & $\begin{array}{l}\text { Sub-bottom } \\
\text { depth }(\mathrm{m})\end{array}$ & $\mathrm{SiO}_{2}$ & $\mathrm{TiO}_{2}$ & $\mathrm{Al}_{2} \mathrm{O}_{3}$ & $\mathrm{Fe}_{2} \mathrm{O}_{3}{ }^{\mathrm{a}}$ & $\mathrm{MnO}$ & $\mathrm{MgO}$ & $\mathrm{CaO}$ & $\mathrm{Na}_{2} \mathrm{O}$ & $\mathrm{K}_{2} \mathrm{O}$ & $\mathrm{P}_{2} \mathrm{O}_{5}$ & $\mathrm{Ba}$ & Co & $\mathrm{Cr}$ \\
\hline $584-1-2,86-88$ & 0.87 & 67.5 & 0.7 & 15.2 & 6.1 & 0.1 & 2.3 & 3.6 & 2.6 & 1.9 & 0.1 & 250 & 12 & 51 \\
\hline $584-2-3,30-32$ & 13.61 & & & & & & & & & & & 567 & & \\
\hline $584-4-1,57-59$ & 29.98 & 83.7 & 0.3 & 7.5 & 3.1 & 0.1 & 1.1 & 1.1 & 1.8 & 1.8 & 0.02 & 605 & 6 & 35 \\
\hline $584-4-2,57-59^{b}$ & 31.48 & & & & & & & & & & & 319 & & \\
\hline $584-5-2,56-58^{b}$ & 40.87 & & & & & & & & & & & 439 & & \\
\hline $584-11-1,78-79$ & 96.79 & & & & & & & & & & & 636 & & \\
\hline $584-11-2,78-79$ & 98.29 & 83.0 & 0.3 & 7.9 & 3.3 & 0.1 & 1.3 & 1.4 & 1.6 & 1.2 & n.d. & & 9 & 47 \\
\hline $584-14-1,34-36$ & 125.05 & 88.0 & 0.2 & 5.0 & 2.4 & n.d. & 0.8 & 1.6 & 1.1 & 0.9 & n.d. & 336 & 5 & 18 \\
\hline $584-20-1,52-54$ & 183.33 & 83.1 & 0.3 & 6.7 & 3.1 & 0.1 & 1.3 & 2.6 & 1.5 & 1.2 & 0.05 & 255 & 7 & 35 \\
\hline $584-22-2,41-43$ & 204.02 & 81.2 & 0.4 & 8.5 & 4.0 & 0.06 & 1.4 & 1.1 & 1.9 & 1.4 & 0.01 & & 5 & 40 \\
\hline $584-24-1,74-76$ & 223.55 & 82.5 & 0.3 & 7.2 & 3.6 & 0.06 & 1.3 & 2.6 & 1.4 & 1.1 & 0.02 & & & \\
\hline $584-27-1,90-92$ & 250.71 & 82.3 & 0.3 & 7.9 & 3.3 & 0.06 & 1.3 & 1.3 & 2.2 & 1.3 & 0.02 & 183 & 8 & 29 \\
\hline $584-29-1,49-50$ & 269.30 & 77.2 & 0.4 & 8.5 & 4.2 & 0.1 & 1.8 & 5.0 & 1.5 & 1.3 & 0.04 & 325 & 11 & 46 \\
\hline $584-32-1,21-22$ & 288.01 & 79.4 & 0.4 & 9.6 & 4.3 & 0.1 & 1.9 & 1.2 & 1.5 & 1.6 & 0.01 & 680 & 11 & 67 \\
\hline $584-36-1,111-112$ & 336.72 & 78.7 & 0.4 & 9.7 & 4.5 & 0.1 & 1.8 & 1.6 & 1.5 & 1.7 & n.d. & 880 & 12 & 43 \\
\hline $584-40-3,108-110$ & 377.79 & 77.9 & 0.4 & 9.7 & 3.8 & 0.1 & 1.7 & 3.7 & 1.8 & 1.7 & 0.04 & 1062 & 14 & 38 \\
\hline $584-46-1,39-40$ & 431.90 & 74.1 & 0.6 & 12.3 & 5.3 & 0.1 & 2.4 & 1.1 & 2.0 & 2.2 & 0.04 & 1328 & 12 & 76 \\
\hline $584-48-1,111-113$ & 451.12 & 73.2 & 0.5 & 12.3 & 5.8 & 0.64 & 2.1 & 1.6 & 1.8 & 2.1 & 0.05 & 1020 & 14 & 65 \\
\hline $584-49-4,49-50$ & 465.10 & 81.0 & 0.4 & 9.4 & 3.9 & 0.1 & 1.4 & 0.8 & 1.2 & 1.7 & 0.02 & 1180 & & \\
\hline $584-53-3,80-81$ & 502.31 & & & & & & & & & & & 873 & 11 & 44 \\
\hline $584-56-1,61-62$ & 527.72 & 77.5 & 0.4 & 11.4 & 3.8 & 0.07 & 1.5 & 1.8 & 1.7 & 2.1 & 0.03 & 1065 & 12 & 40 \\
\hline $584-60-3,1-2$ & 568.12 & 68.7 & 0.8 & 14.6 & $\begin{array}{l}5.0 \\
6.6\end{array}$ & 0.1 & 3.0 & 1.6 & 2.2 & 2.5 & n.d. & 1052 & 15 & 124 \\
\hline $584-67-2,84-85$ & 634.45 & 69.7 & 0.7 & 14.2 & 6.3 & 0.1 & 2.6 & 1.3 & 2.5 & 2.5 & 0.07 & 1015 & 15 & 120 \\
\hline $584-70-1,46-47$ & 661.67 & 72.0 & 0.7 & 13.6 & 5.7 & 0.1 & 2.5 & 1.2 & 1.9 & 2.3 & 0.04 & 1059 & 16 & 110 \\
\hline $584-76-2,77-78$ & 721.38 & 73.6 & 0.6 & 12.5 & 5.5 & 0.1 & 2.7 & 1.1 & 1.8 & 2.2 & n.d. & & 15 & 84 \\
\hline $584-80-1,106-107$ & 758.57 & 80.8 & 0.4 & 9.7 & 3.5 & 0.1 & 1.4 & 0.7 & 1.5 & 1.9 & n.d. & 793 & & \\
\hline $584-86-1,103-104$ & 816.53 & 79.0 & 0.4 & 9.7 & 4.9 & 0.1 & 1.9 & 0.7 & 1.5 & 1.9 & 0.01 & & 24 & 53 \\
\hline $584-90-2,128-129$ & 856.78 & 77.7 & 0.4 & 10.2 & 4.8 & 0.5 & 1.6 & 1.1 & 1.6 & 2.1 & 0.03 & 767 & 25 & 68 \\
\hline $584-94-1,29-30$ & 893.10 & 72.3 & 0.6 & 13.0 & 6.1 & 0.6 & 2.3 & 0.9 & 2.0 & 2.3 & 0.03 & 593 & 26 & 76 \\
\hline $584-96-2,141-142^{c}$ & 914.12 & & & & & & & & & & & 357 & & \\
\hline $584-97-1,100-101$ & 922.81 & 76.3 & 0.5 & 11.6 & 5.0 & 0.1 & 1.6 & 1.8 & 1.5 & 1.7 & 0.03 & 793 & 14 & 39 \\
\hline
\end{tabular}

Note: Blank: not analyzed; n.d.: not detected.

Total iron as $\mathrm{Fe}_{2} \mathrm{O}_{3}$.

b Diatomaceous fraction of the sediment sample.

c Volcanic ash fraction.

near the Miocene/Pliocene boundary. A negative $\mathrm{Ce}$ anomaly for the Cretaceous chert suggests a hydrothermal origin.

\section{COMPARISON OF GEOCHEMISTRY OF NANKAI TROUGH AND JAPAN TRENCH DEEP-SEA SEDIMENTS}

Major and minor element geochemistry reveals that sediments recovered from the Nankai Trough (Sites 582 and 583) and the Shikoku Basin (Sites 296 and 297) are similar to one another, meaning that their source has not changed appreciably throughout the interval from the late Miocene to the present. The geochemical characteristics of the Pliocene-Pleistocene sediments from Sites 584, 439, and 436, near the Japan Trench, are also similar to each other, but different from those of the Nankai Trough and the Shikoku Basin sediments (compare Tables 2, 3, 4, 5, and 6). For example, the $\mathrm{SiO}_{2}$ concentration ranges from about 70 to $90 \%$ in the Japan Trench, but from 50 to $70 \%$ in the Nankai Trough and the Shikoku Basin, a difference attributable to the abundance of biogenic silica. 
Table 3. (Continued).

\begin{tabular}{|c|c|c|c|c|c|c|c|c|c|c|c|c|c|c|c|c|c|c|c|c|}
\hline Cs & $\mathrm{Cu}$ & $\mathrm{Hf}$ & $\mathrm{Ni}$ & $\mathrm{Rb}$ & Sb & $\mathrm{Sc}$ & $\mathrm{Sr}$ & $\mathrm{Ta}$ & Th & $\mathrm{U}$ & V & $\mathrm{Zn}$ & $\mathrm{Zr}$ & $\mathrm{La}$ & $\mathrm{Ce}$ & $\mathrm{Sm}$ & $\mathrm{Eu}$ & $\mathrm{Tb}$ & $\mathrm{Yb}$ & Lu \\
\hline 3.8 & 44 & 2.1 & 39 & 72 & & 10.0 & 510 & 0.67 & 6.3 & & 65 & 108 & 126 & 22.9 & 44 & 4.18 & 0.89 & 0.88 & 2.6 & 0.53 \\
\hline \multirow[t]{2}{*}{3.0} & 24 & 2.1 & 10 & 59 & & 6.9 & 677 & 0.41 & 5.5 & & 37 & 65 & 141 & 19.6 & 38 & 3.63 & 0.68 & 0.73 & 2.9 & 0.38 \\
\hline & 34 & & 11 & 69 & & & 517 & & & & 45 & 75 & 174 & & & & & & & \\
\hline 4.1 & 15 & 1.9 & 12 & 54 & 0.48 & 8.4 & 811 & 0.53 & 6.4 & 1.1 & 37 & 58 & 119 & 24.4 & 37 & 3.92 & 0.90 & 0.60 & 2.2 & 0.35 \\
\hline 2.3 & 19 & 1.4 & & 36 & & 5.8 & 919 & 0.36 & 3.7 & & 24 & 56 & 118 & 16.2 & 43 & 2.94 & 0.71 & 0.63 & 2.0 & 0.38 \\
\hline 3.8 & 48 & 1.7 & 17 & 55 & & 8.1 & 810 & 0.42 & 6.1 & & 41 & 61 & 118 & 23.6 & 40 & 4.28 & 0.95 & 0.93 & 2.6 & 0.37 \\
\hline 2.1 & 22 & 1.1 & 11 & 33 & 0.23 & 5.5 & 1014 & 0.34 & 3.7 & 0.8 & 29 & 42 & 113 & 17.5 & 29 & 2.89 & 0.71 & 0.41 & 1.5 & 0.27 \\
\hline \multirow[t]{2}{*}{2.5} & 77 & 1.3 & 19 & 33 & 0.33 & 5.9 & 987 & 0.24 & 4.6 & 0.8 & 21 & 52 & 100 & 20.6 & 24 & 3.76 & 0.90 & 0.67 & 2.1 & 0.32 \\
\hline & 21 & & & 12 & & & 809 & & & & 23 & 39 & 86 & & & & & & & \\
\hline \multirow[t]{2}{*}{5.2} & 71 & 2.6 & 48 & 117 & 0.65 & 11.9 & 220 & 0.76 & 8.2 & & 98 & 118 & 151 & 25.5 & 55 & 4.25 & 0.93 & 0.55 & 2.7 & 0.44 \\
\hline & 58 & & 55 & 121 & & & 147 & & & & 104 & 120 & 153 & & & & & & & \\
\hline 6.4 & 120 & 3.0 & 56 & 135 & 0.49 & 13.7 & 118 & 0.84 & 9.8 & & 122 & 105 & 138 & 31.6 & 67 & 5.15 & 1.13 & 0.75 & 3.3 & 0.49 \\
\hline 2.6 & & 2.1 & & & 0.99 & 19 & & 0.31 & 4.9 & 0.7 & & & & 36.0 & 53 & 8.08 & 2.07 & 1.34 & 4.5 & 0.73 \\
\hline
\end{tabular}

Table 4. (Continued).

\begin{tabular}{|c|c|c|c|c|c|c|c|c|c|c|c|c|c|c|c|c|c|c|c|c|}
\hline Cs & $\mathrm{Cu}$ & $\mathrm{Hf}$ & $\mathrm{Ni}$ & $\mathrm{Rb}$ & $\mathrm{Sb}$ & $\mathrm{Sc}$ & $\mathrm{Sr}$ & $\mathrm{Ta}$ & Th & $\mathrm{U}$ & v & $\mathrm{Zn}$ & $\mathrm{Zr}$ & $\mathrm{La}$ & $\mathrm{Ce}$ & $\mathrm{Sm}$ & $\mathrm{Eu}$ & $\mathrm{Tb}$ & $\mathrm{Yb}$ & Lu \\
\hline 2.8 & 56 & 2.5 & 28 & 51 & 0.54 & 17 & 237 & 0.3 & 4.0 & 3.7 & 100 & 112 & 117 & 13.0 & 28 & 3.2 & 0.86 & 0.62 & 2.7 & 0.52 \\
\hline 1.6 & & 1.4 & & & 0.46 & 6.8 & & 0.18 & 2.7 & 2.0 & & & & 9.1 & 19 & 1.88 & 0.40 & 0.34 & 1.3 & 0.27 \\
\hline 2.4 & 53 & 1.6 & 24 & 44 & 0.69 & 7.7 & 108 & 0.21 & 2.8 & 1.7 & 42 & 85 & 80 & 8.6 & 16 & 1.9 & 0.47 & 0.37 & 1.6 & 0.29 \\
\hline 1.0 & & 2.0 & & & 0.77 & 4.4 & & & 2.0 & 1.0 & & & & & & & & & & \\
\hline 1.7 & & 1.8 & & & 0.64 & 4.6 & & 0.22 & 3.8 & & & & & 11.9 & 23 & 2.18 & 0.58 & 0.30 & 1.9 & 0.31 \\
\hline 2.3 & & 1.7 & & & 0.64 & 9.3 & & 0.22 & 3.0 & 2.0 & & & & 9.8 & 20 & 1.9 & 0.53 & 0.37 & 1.4 & 0.23 \\
\hline 1.6 & 85 & 1.7 & 34 & 44 & 0.59 & 8.6 & 120 & 0.27 & 2.7 & & 61 & 104 & 72 & 9.3 & 19 & 1.9 & 0.39 & 0.43 & 1.3 & 0.22 \\
\hline 1.4 & 79 & 1.1 & 31 & 28 & 0.44 & 5.2 & 114 & 0.13 & 1.7 & 1.2 & 43 & 82 & 41 & 5.5 & 8.6 & 1.2 & 0.33 & 0.25 & 1.0 & 0.19 \\
\hline \multirow[t]{2}{*}{2.2} & 50 & 1.4 & 36 & 39 & 0.53 & 8.3 & 144 & 0.19 & 2.8 & 2.1 & 38 & 85 & 65 & 8.6 & 19 & 1.8 & 0.45 & 0.29 & 1.3 & 0.29 \\
\hline & 58 & & 35 & 43 & & & 119 & & & & 44 & 100 & 67 & & & & & & & \\
\hline 2.2 & 70 & 1.6 & 38 & 43 & 0.52 & 7.5 & 112 & 0.14 & 2.6 & 1.4 & 44 & 84 & 79 & 8.0 & 18 & 1.8 & 0.40 & 0.42 & 1.5 & 0.29 \\
\hline 2.2 & 59 & 2.0 & 43 & 42 & 0.59 & 9.7 & 221 & 0.24 & 3.0 & 1.9 & 51 & 93 & 80 & 9.4 & 16 & 2.15 & 0.47 & 0.51 & 1.5 & 0.33 \\
\hline 3.5 & 83 & 1.8 & 48 & 57 & 0.77 & 10.2 & 126 & 0.32 & 3.9 & 1.8 & 72 & 103 & 87 & 11.1 & 24 & 2.2 & 0.59 & 0.39 & 1.7 & 0.30 \\
\hline 3.2 & 80 & 1.8 & 49 & 57 & 0.56 & 9.5 & 137 & 0.28 & 3.8 & 2.5 & 74 & 108 & 84 & 11.6 & 27 & 2.4 & 0.60 & 0.44 & 2.3 & 0.43 \\
\hline 3.2 & 76 & 1.8 & 55 & 56 & 0.54 & 10.0 & 203 & 0.28 & 4.3 & 2.7 & 69 & 115 & 85 & 13.1 & 29 & 2.6 & 0.65 & 0.46 & 2.1 & 0.39 \\
\hline 4.3 & 113 & 2.4 & 44 & 74 & 0.63 & 11.8 & 157 & 0.41 & 5.0 & 1.6 & 100 & 105 & 107 & 16.0 & 33 & 2.8 & 0.73 & 0.34 & 1.6 & 0.31 \\
\hline 4.0 & 53 & 3.1 & 65 & 65 & 0.86 & 13 & 150 & 0.47 & 5.7 & 1.8 & 85 & 125 & 100 & 17.7 & 38 & 3.7 & 0.86 & 0.83 & 2.4 & 0.44 \\
\hline \multirow[t]{2}{*}{3.3} & & 1.8 & & & 0.57 & 9.0 & & 0.27 & 4.0 & 1.3 & & & & 11.5 & 23 & 2.2 & 0.56 & 0.31 & 1.2 & 0.27 \\
\hline & 93 & & 38 & 61 & 0.55 & & 112 & & & 1.5 & 68 & 106 & 78 & 13.4 & 35 & 2.68 & 0.43 & 0.44 & 1.8 & 0.34 \\
\hline 3.7 & 65 & 2.4 & 37 & 62 & 0.51 & 9.4 & 140 & 0.32 & 4.9 & 1.6 & 67 & 113 & 110 & 14.1 & 41 & 2.9 & 0.74 & 0.49 & 2.4 & 0.42 \\
\hline 4.8 & 49 & 3.1 & 56 & 81 & 0.41 & 14.5 & 158 & 0.49 & 6.3 & 1.5 & 118 & 94 & 129 & 18.7 & 59 & 3.6 & 0.83 & 0.52 & 2.8 & 0.40 \\
\hline 5.3 & 52 & 4.1 & 60 & 83 & 0.30 & 15 & 150 & 0.63 & 6.5 & 1.8 & 120 & 100 & 120 & 18.6 & 36 & 3.9 & 0.93 & 0.61 & 2.4 & 0.44 \\
\hline \multirow[t]{2}{*}{5.2} & 87 & 2.9 & 68 & 78 & 0.42 & 13.5 & 140 & 0.49 & 6.0 & 1.3 & 115 & 110 & 116 & 17.5 & 38 & 3.4 & 0.85 & 0.57 & 2.2 & 0.37 \\
\hline & 80 & & 54 & 78 & & & 140 & & & & 97 & 116 & 111 & & & & & & & \\
\hline \multirow[t]{2}{*}{3.5} & & 2.0 & & & 0.70 & 8.8 & & 0.34 & 4.7 & 0.8 & & & & 14 & 31 & 2. & 0.65 & 0. & 1.9 & 0.33 \\
\hline & 125 & & 75 & 73 & & & 104 & & & & 73 & 125 & 90 & 18.6 & 42 & 3.9 & 0.88 & 0.44 & 2.5 & 0.34 \\
\hline 4.3 & 101 & 2.3 & 123 & 69 & 0.8 & 11.5 & 111 & 0. & 5. & 1. & 69 & 155 & 106 & 18.4 & 42 & 3. & 0.78 & 0.51 & 2.2 & 0.37 \\
\hline \multirow[t]{2}{*}{6.2} & 169 & 3.3 & 90 & 89 & 0.95 & 13 & 110 & 0.66 & 7.6 & 2.3 & 93 & 160 & 107 & 19.3 & 49 & 3.7 & 0.78 & 0.55 & 2.0 & 0.43 \\
\hline & & 1.8 & & & 0.77 & 5. & & 0.77 & 7.0 & 2.4 & & & & 12.9 & 27 & 3.96 & 0.25 & 0.98 & 3.8 & 0.60 \\
\hline 4.1 & 92 & 1.7 & 52 & 64 & 0.88 & 12.6 & 135 & 0.33 & 4.7 & 1.2 & 82 & 125 & 83 & 13.9 & 33 & 2.8 & 0.71 & 0.59 & 2.0 & 0.33 \\
\hline
\end{tabular}

The LILs are more enriched in the sediments in the Nankai Trough and the Shikoku Basin than in the Japan Trench, a trend observed not only in major-element oxides, such as $\mathrm{Na}_{2} \mathrm{O}$ and $\mathrm{K}_{2} \mathrm{O}$, but also in trace elements, such as $\mathrm{La}$ and $\mathrm{Yb}$. These differences imply that the sediments in these regions differ not only in the ratio of biogenic silica to terrigenous clastics but also in the chemical characteristics of terrigenous suites. The LILs are more concentrated in the Miocene than in the Pliocene sediment. In other words, the LIL concentrations of the Miocene sediments in the Japan Trench are like the Pliocene to Recent sediments in the Nankai Trough region. The similarity is confirmed by comparing not only the LILs but also the $\mathrm{La} / \mathrm{Yb}, \mathrm{U} / \mathrm{Th}$, and $\mathrm{Na}_{2} \mathrm{O} / \mathrm{K}_{2} \mathrm{O}$ ratios.
During the Miocene, sediments of similar chemical composition may have been supplied to the Japan Trench, the Nankai Trough, and the Shikoku Basin. Changes of ocean currents might explain variations in their present geochemistry (Fig. 10). During the Miocene, the Kuroshio flowed from the Shikoku Basin toward the shore of northeastern Japan and carried huge amounts of terrigenous sediments off the Japanese islands along its path. In the Pliocene, the current shifted to a more easterly course and did not reach the Japan Trench region. Fine grains suspended in the open ocean can travel more than $1000 \mathrm{~km}$ in strong ocean current (Reed et al., 1975). Such transport of suspended particles by the Kuroshio may possibly account for the sedimentation of geochem- 


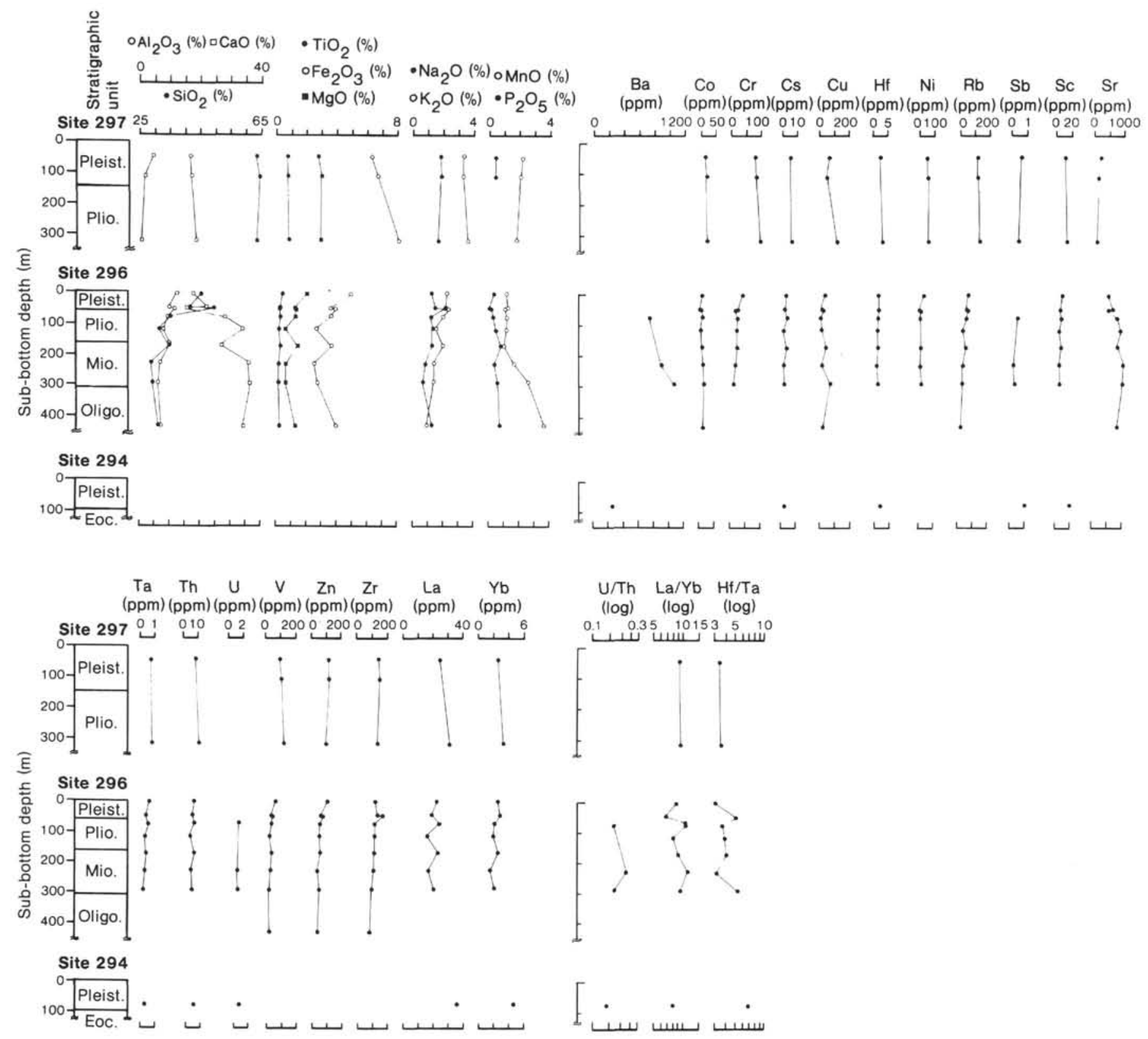

Figure 4. Depth profiles for concentrations of major, minor, and trace elements in deep-sea sediments from Sites 294, 296, and 297.

ically similar materials in very wide regions offshore of the Japanese islands.

\section{CONCLUSIONS}

The following conclusions are drawn from chemical analysis of the deep-sea sediments in the Nankai Trough and the Japan Trench:

1. Sources of the Pliocene to Quaternary sediments were similar in the Nankai Trough and the northern part of the Shikoku Basin.

2. The REE pattern varies in the Miocene to Quaternary sediments at Site 296 . The change reflects the motion of the Philippine Sea Plate, which is migrating northward toward the islands of Japan.

3. The source supplying sediment to the Japan Trench changed near the boundary between the Pliocene and the Miocene.
4. During the Miocene, geochemically similar terrigenous sediments were supplied to a large area of the $\mathrm{Pa}$ cific Ocean side of the Japanese islands, including the Shikoku Basin, the Nankai Trough, and the Japan Trench. This supply might have been caused by the Kuroshio flowing northeast along the Japanese islands.

5. Negative cerium anomalies in sediments are an indicator of the hydrothermal activity.

\section{ACKNOWLEDGMENTS}

We are indebted to Professors N. Nasu and H. Kagami for giving us an opportunity to study these sediments, and to Professor A. Iijima for his interest. Thanks are also due Professor H. Wakita and Dr. Y. Nakamura for generously permitting us to use their facility. We would like to express sincere thanks to Professors A. Masuda and H. Wakita for their valuable suggestions and critical reading of this manuscript. This work was supported in part by a grant from Ito Science Foundation. 


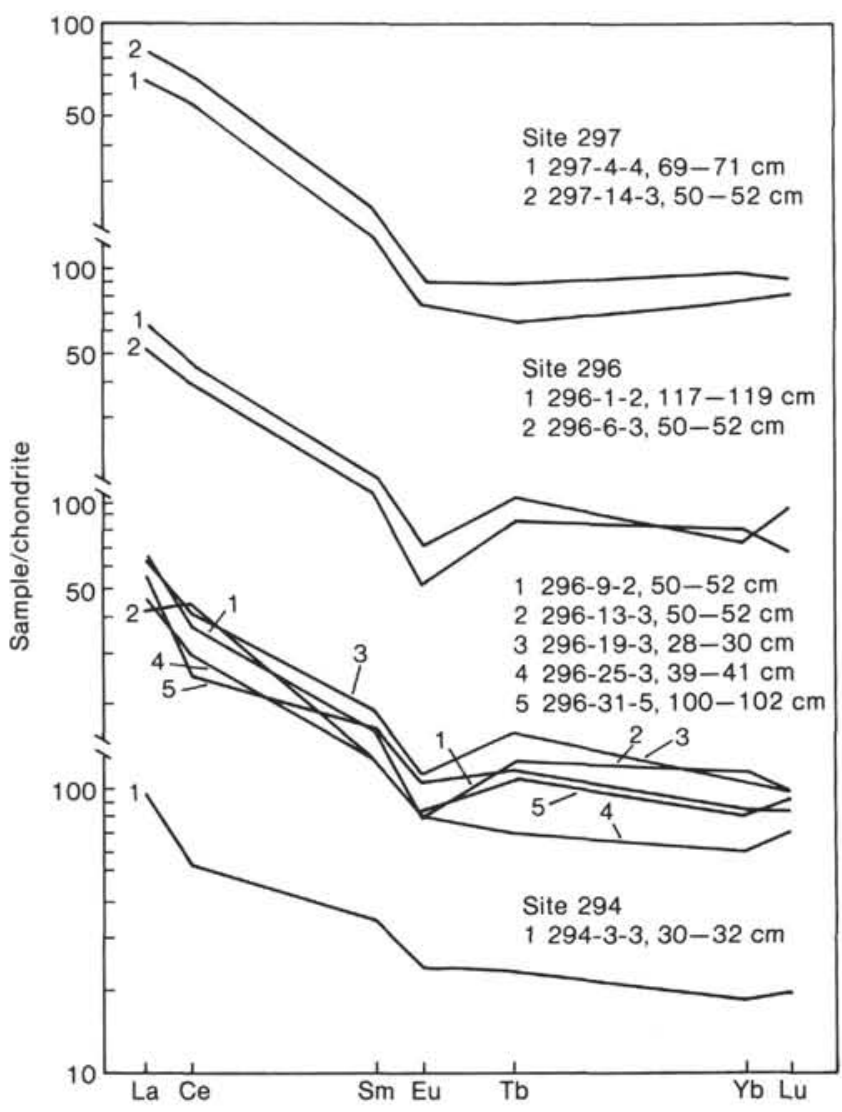

Figure 5. Typical chondrite-normalized rare-earth-element patterns for deep-sea sediments from Sites 294, 296, and 297.

\section{REFERENCES}

Bogdanov, Yu. A., Lisitzin, A. P., Lukashin, V. N., Gordeev, V. V., Zverinskaya, I. B., Zeljdina, B. B., Kuzinov, A. D., and Zhivago, V. N., 1976. Chemical composition of sediments. In Hollister, C. D., Craddock, C., et al., Init. Repts. DSDP, 35, Washington (U.S. Govt. Printing Office), 447-464.

Dymond, J., Corliss, J. B., and Stillinger, R., 1976. Chemical composition and metal accumulation rates of metalliferous sediments from Sites 319, 320, and 321. In Yeats, R. S., Hart, S. R., et al., Init. Repts. DSDP, 34, Washington (U.S. Govt. Printing Office), 575588.

Gurvich, Y. G., Bogdanov, Y. A., and Lisitsyn, A. P., 1978. Behavior of barium in recent sedimentation in the Pacific. Geokhimiya, 3: 359-374.

Karig, D. E., Ingle, J. C., Jr., et al., 1975. Init. Repts. DSDP, 31, Washington (U.S. Govt. Printing Office).

Matsumoto, R., Minai, Y., and IIjima, A., in press. Manganese content, cerium anomaly, and rate of sedimentation as clues to charac- terize and classify deep sea sediments. In Nasu, N., Kobayashi, K., and Kagami, H. (Eds.), Formation of Ocean Margins: Tokyo (Terra Pub.).

Matsumoto, R., and Urabe, T., 1980. An automatic analysis of major elements in silicate rocks with X-ray fluorescence spectrometer using fused disc samples. J. Jap. Assoc. Mineral. Petrol. Econ. Geol., 76:111-121.

Minai, Y., 1982. Geochemical studies of the ocean floor rocks and sediments [doctoral thesis]. University of Tokyo, Tokyo. (In Japanese)

Piper, D. Z., 1974. Rare earth elements in the sedimentary cycle: a summary. Chem. Geol., 14:285-304.

Rangin, C., Steinberg, M., and Bonnot-Courtois, C., 1981. Geochemistry of the Mesozoic bedded cherts of central Baja California (Vizcaino-Cedros-San Benito): implications for paleogeographic reconstruction of an old oceanic basin. Earth Planet. Sci. Lett., 54:313-322.

Reed, W. E., Le Fever, R., and Moir, G. J., 1975. Depositional environment interpretation from settling velocity distribution. Geol. Soc. Am. Bull., 86:1321-1328.

Scientific Party, 1980. Init. Repts. DSDP, 56, 57: Washington (U.S. Govt. Printing Office).

Shimizu, H., and Masuda, A., 1977. Cerium in chert as an indication of marine environment of its formation. Nature, 266:346-348.

Steinberg, M., Bonnot-Courtois, C., and Tlig, S., 1983. Geochemical contribution to the understanding of bedded cherts. In Iijima, A., Hein, J. R., and Siever, R. (Eds.), Siliceous Deposits in Pacific Region: Amsterdam (Elsevier), pp. 193-210.

Steinberg, M., and Marin, C. M., 1978. Classification géochimique des radiolarites et des sédiments silicieux océaniques, signification paleo-océanographique. Oceanol. Acta, 1:359-367.

Sugisaki R., 1978. Chemical composition of argillaceous sediments on the Pacific margin of southeast Japan. Geol. Surv. Japan Cruise Rept., 6:65-73.

1979. Chemical composition of argillaceous sediments around the Yamato Bank in the Japan Sea. Geol. Surv. Japan Cruise Rept., 13:75-88.

, 1980a. Major-element chemistry of argillaceous sediments, at Deep Sea Drilling Project Sites 442, 443, and 444, Shikoku Basin. In Klein, G. deV., Kobayashi, K., et al., Init. Repts. DSDP, 58: Washington (U.S. Govt. Printing Office), 719-735.

, 1980b. Major element chemistry of the Japan Trench sediments, Legs 56 and 57. In Scientific Party, Init. Repts. DSDP, 56, 57, Pt. 2: Washington (U.S. Govt. Printing Office), 1233-1249.

Tarney, J., and Donnellan, N. C. B., 1977. Minor element geochemistry of sediments at Site 328, Falkland Outer Basin and Site 329, Falkland Plateau, Leg 36, Deep Sea Drilling Project. In Barker, P. F., Dalziel, I. W. D., et al., Init. Repts. DSDP, 36: Washington (U.S. Govt. Printing Office), 929-939.

von Huene, R., Langseth, M., Nasu, N., and Okada, H., 1982. A summary of Cenozoic tectonic history along the IPOD Japan Trench transect. Geol. Soc. Am. Bull., 93:829-846.

Date of Initial Receipt: 4 January 1984 Date of Acceptance: 8 May 1985 

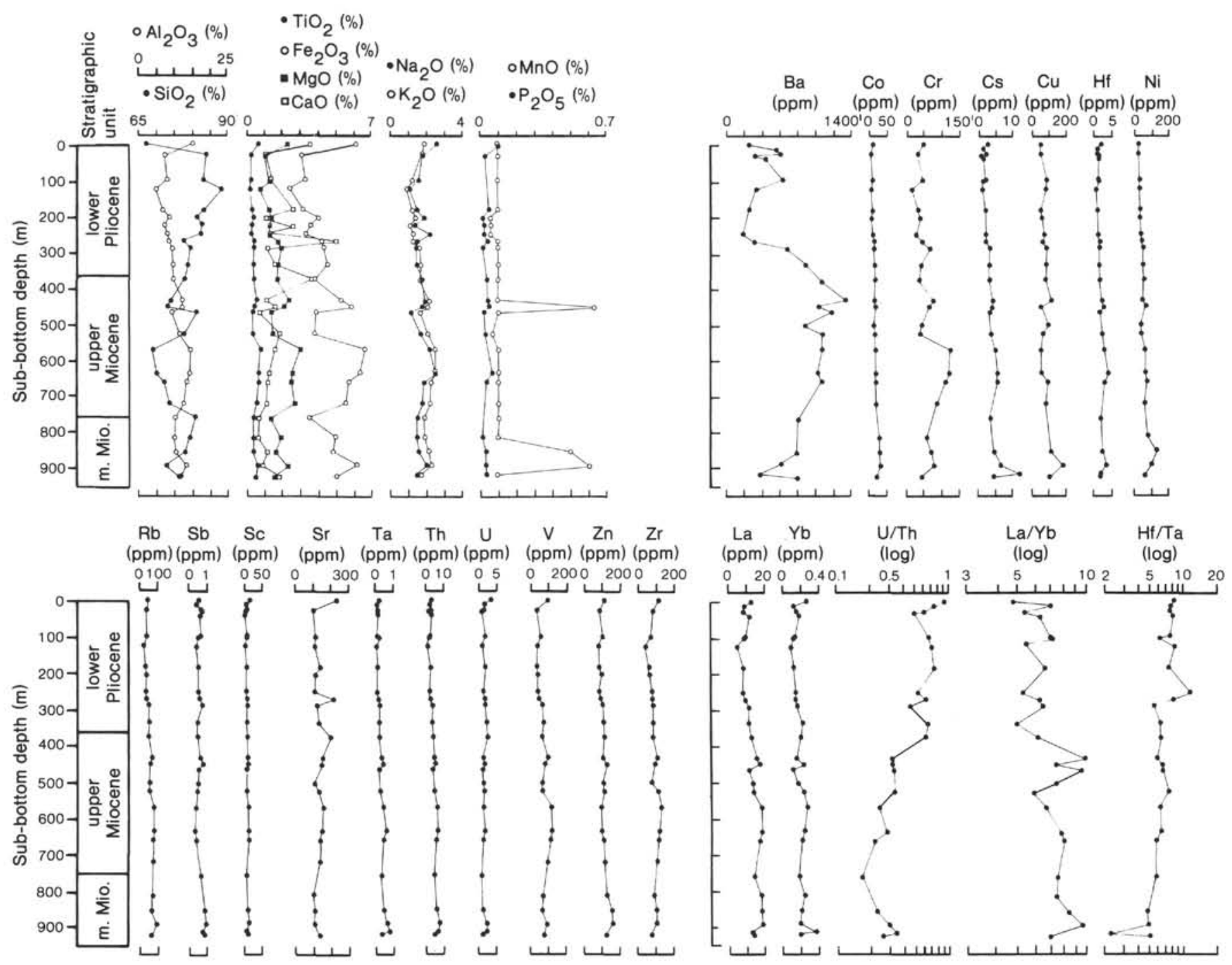

Figure 6. Depth profiles for concentrations of major, minor, and trace elements in deep-sea sediments from Site 584.

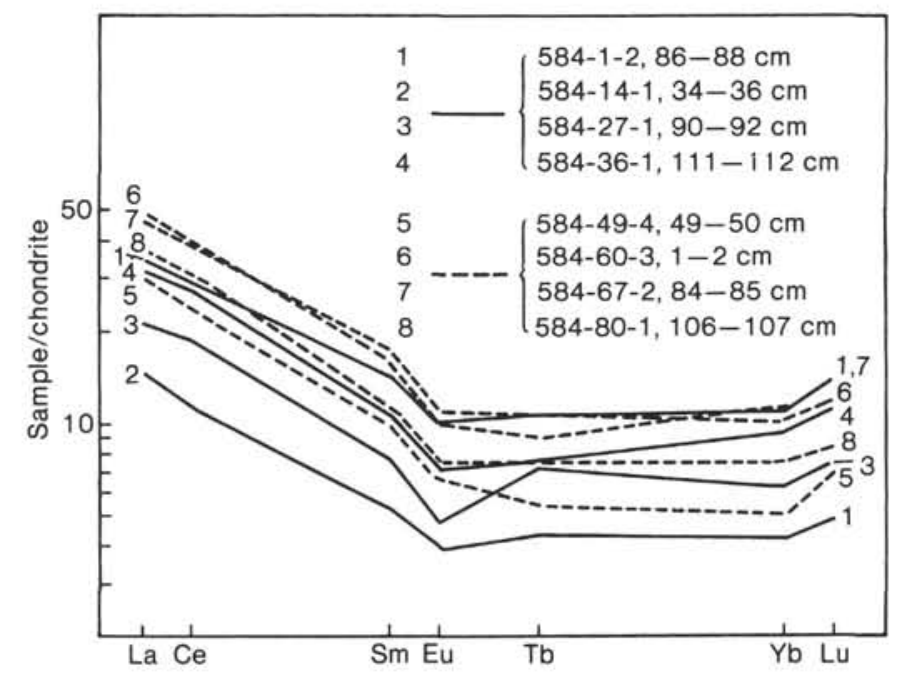

Figure 7. Chondrite-normalized rare-earth-element patterns for several deep-sea sediments from Site 584 . 
Table 5. Site 439: concentrations of major-element oxides (wt.\%) in deep-sea sediments.

\begin{tabular}{lccccccccccc}
\hline $\begin{array}{c}\text { Hole-Core-Section } \\
\text { (interval in cm) }\end{array}$ & $\begin{array}{c}\text { Sub-bottom } \\
\text { depth }(\mathrm{m})\end{array}$ & $\mathrm{SiO}_{2}$ & $\mathrm{TiO}_{2}$ & $\mathrm{Al}_{2} \mathrm{O}_{3}$ & $\mathrm{Fe}_{2} \mathrm{O}_{3}{ }^{\mathrm{a}}$ & $\mathrm{MnO}$ & $\mathrm{MgO}$ & $\mathrm{CaO}$ & $\mathrm{Na}_{2} \mathrm{O}$ & $\mathrm{K}_{2} \mathrm{O}$ & $\mathrm{P}_{2} \mathrm{O}_{5}$ \\
\hline $439-37-1,96-98$ & 1144.97 & 68.7 & 0.53 & 17.3 & 5.6 & 0.06 & 1.56 & 1.07 & 2.14 & 3.11 & 0.01 \\
$439-38-1,107-109$ & 1149.08 & 67.0 & 0.83 & 18.2 & 5.9 & 0.06 & 2.01 & 0.42 & 2.05 & 3.48 & 0.06 \\
$439-39-1,32-34$ & 1153.83 & 65.5 & 0.85 & 19.0 & 6.5 & 0.06 & 2.07 & 0.38 & 1.80 & 3.74 & 0.05 \\
\hline
\end{tabular}

a Total iron as $\mathrm{Fe}_{2} \mathrm{O}_{3}$.

Table 6. Site 436: INAA results (in ppm) for deep-sea sediments.

\begin{tabular}{|c|c|c|c|c|c|c|c|c|c|c|c|c|c|c|c|}
\hline $\begin{array}{l}\text { Hole-Core-Section } \\
\text { (interval in } \mathrm{cm} \text { ) }\end{array}$ & $\begin{array}{l}\text { Sub-bottom } \\
\text { depth }(m)\end{array}$ & Cs & Hf & $\mathrm{Sb}$ & $\mathrm{Sc}$ & $\mathrm{Ta}$ & Th & $U$ & $\mathrm{La}$ & $\mathrm{Ce}$ & $\mathrm{Sm}$ & Eu & $\mathrm{Tb}$ & $\mathrm{Yb}$ & $\mathrm{Lu}$ \\
\hline $436-3-1,60-62$ & 18.10 & 3.8 & 2.4 & 0.74 & 14 & 0.60 & 5.9 & & 17.5 & 40 & 4.47 & 0.83 & 0.88 & 2.7 & 0.46 \\
\hline $436-12-2,60-62$ & 105.11 & 2.6 & 1.6 & 0.65 & 14 & 0.35 & 4.1 & & 13.6 & 29 & 3.54 & 0.85 & 0.69 & 2.4 & 0.56 \\
\hline $436-19-3,140-142$ & 173.91 & 2.6 & 1.8 & 0.42 & 12 & 0.39 & 4.4 & & 13.1 & 31 & 3.41 & 0.72 & 0.73 & 2.2 & 0.47 \\
\hline $436-23-4,70-72$ & 212.71 & 4.3 & 2.5 & 0.67 & 13 & 0.50 & 6.3 & & 19.5 & 39 & 3.83 & 0.87 & 0.60 & 2.6 & 0.52 \\
\hline $436-31-3,130-132$ & 287.81 & 3.6 & 2.1 & 0.69 & 12 & 0.50 & 5.8 & & 20.3 & 44 & 3.86 & 0.86 & 0.63 & 2.4 & 0.44 \\
\hline $436-34-2,74-75$ & 314.25 & 5.4 & 2.4 & 0.72 & 14 & 0.60 & 7.9 & & 24.3 & 5.3 & 4.38 & 0.96 & 0.64 & 2.6 & 0.42 \\
\hline $436-38-5,34-36$ & 356.35 & 6.1 & 2.5 & 0.56 & 15 & 0.66 & 9.7 & & 26.0 & 69 & 5.22 & 1.22 & 0.87 & 3.0 & 0.58 \\
\hline $436-39-5,42-43$ & 365.93 & 6.8 & 3.7 & 1.16 & 21 & 0.91 & 15.5 & 19.9 & 41.8 & 136 & 9.58 & 2.31 & 1.70 & 5.8 & 0.97 \\
\hline $436-41-1,43-45^{\mathrm{a}}$ & 378.94 & 0.39 & 0.21 & 0.34 & 2.1 & 0.05 & 0.3 & 1.7 & 2.3 & 5.4 & 0.83 & 0.20 & 0.12 & 0.30 & 0.10 \\
\hline $436-41-1,43-45^{b}$ & 378.94 & 0.26 & 0.16 & 0.13 & 1.3 & 0.03 & 0.2 & 1.9 & 1.8 & 3.4 & 0.60 & 0.14 & 0.11 & 0.22 & 0.10 \\
\hline $436-41-1,46-48$ & 378.97 & 0.93 & 0.53 & 0.27 & 3.6 & 0.13 & 1.5 & 1.0 & 15.2 & 13 & 3.58 & 0.81 & 0.55 & 1.8 & 0.32 \\
\hline
\end{tabular}

Note: INAA: instrumental neutron activation analysis; blank: not analyzed.

a Reddish brown fraction of the chert sample.

b Noncolored white fraction of the chert sample. 

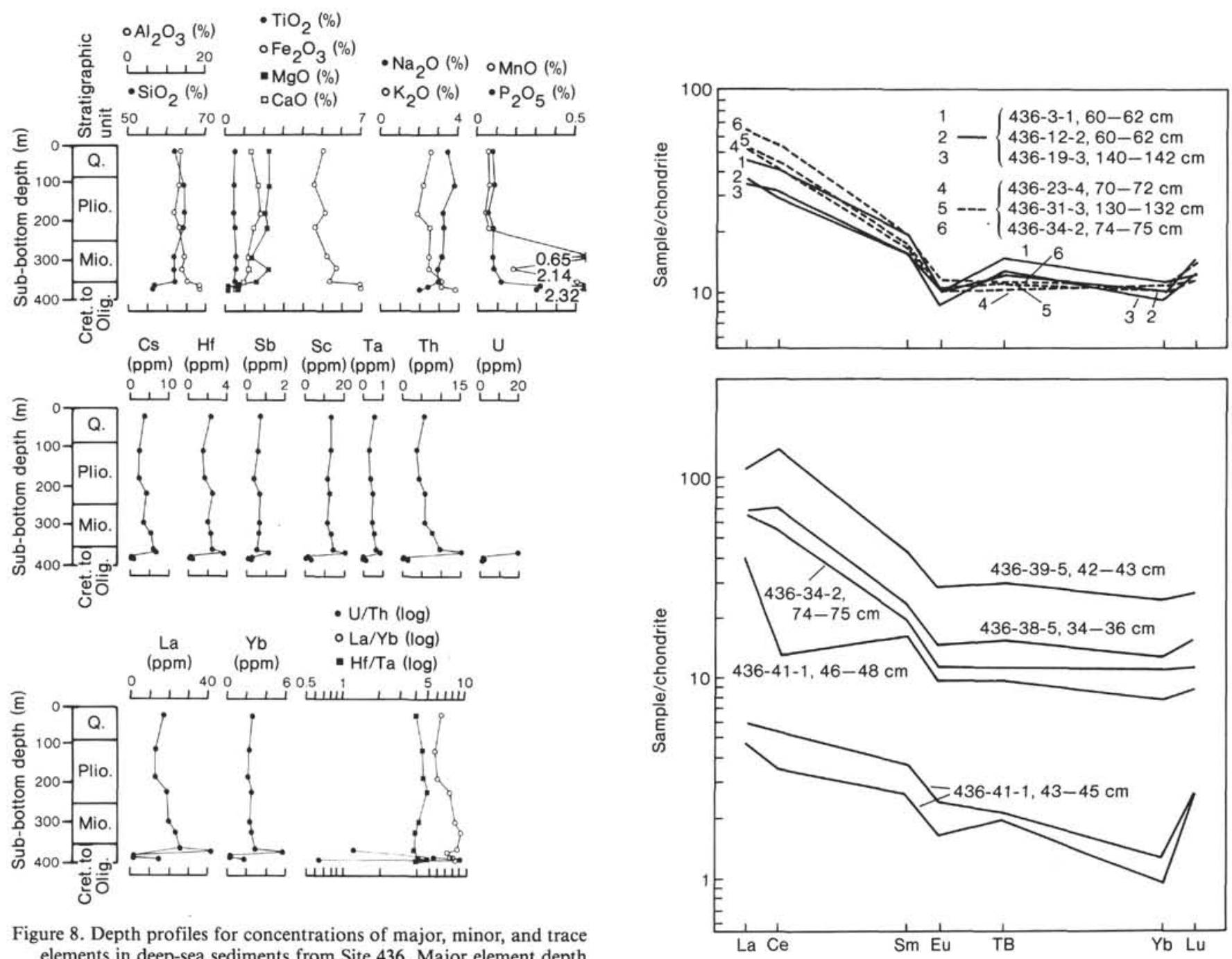

Figure 8. Depth profiles for concentrations of major, minor, and trace elements in deep-sea sediments from Site 436. Major element depth profiles were drawn from Sugisaki (1980b). The samples represented in the major element depth profiles are as follows (all from Hole 436, expressed in core-section, interval in cm): 3-3, 100-104; $12-2,36-40 ; 19-4,86-90 ; 23-5,35-39 ; 31-4,40-44 ; 34-2,60-64$;

Figure 9. Typical chondrite-normalized rare-earth-element patterns of deep-sea sediments from Site 436. 


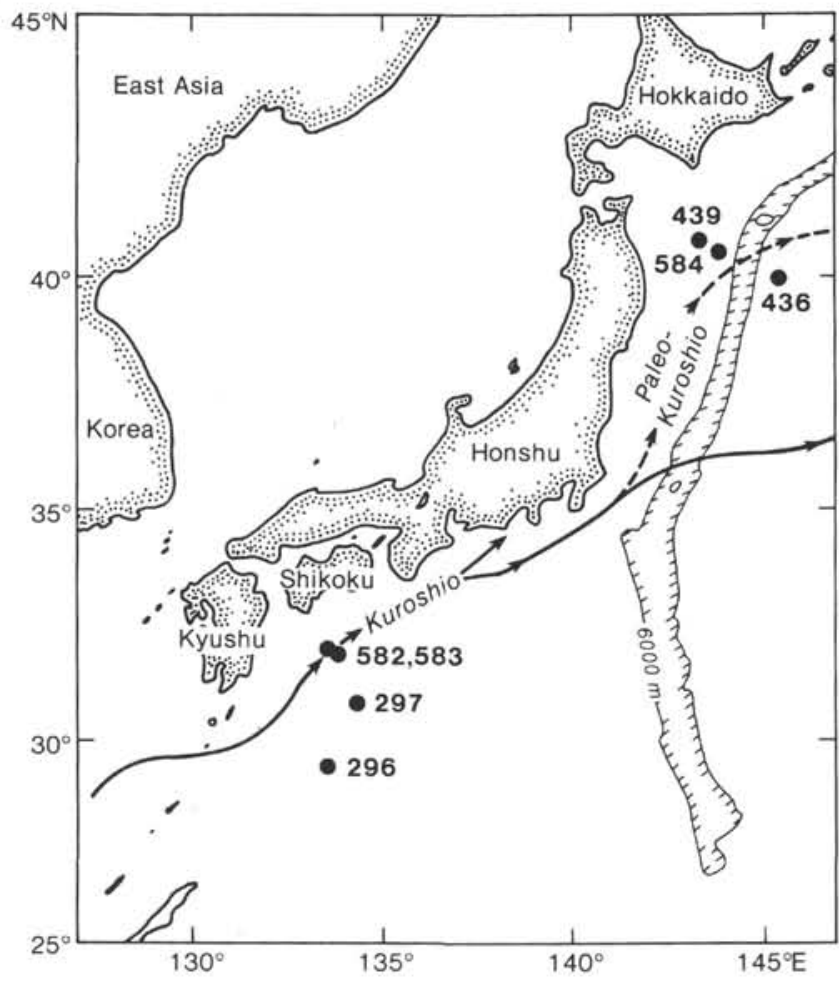

Figure 10. The proposed model for the sedimentation process in the south of the Japan islands from the Miocene to the Quaternary. 